\title{
Biological Materials: The Next Frontier for Cell-Free Synthetic Biology
}

\author{
Richard J. R. Kelwick', Alexander J. Webb ${ }^{1}$ and Paul S. Freemont ${ }^{1,2,3 *}$ \\ ${ }^{1}$ Section of Structural and Synthetic Biology, Department of Infectious Disease, Imperial College London, London, \\ United Kingdom, ${ }^{2}$ The London Biofoundry, Imperial College Translation \& Innovation Hub, London, United Kingdom, ${ }^{3}$ UK \\ Dementia Research Institute Care Research and Technology Centre, Imperial College London, London, United Kingdom
}

Advancements in cell-free synthetic biology are enabling innovations in sustainable biomanufacturing, that may ultimately shift the global manufacturing paradigm toward localized and ecologically harmonized production processes. Cell-free synthetic biology strategies have been developed for the bioproduction of fine chemicals, biofuels and biological materials. Cell-free workflows typically utilize combinations of purified enzymes, cell extracts for biotransformation or cell-free protein synthesis reactions, to assemble and characterize biosynthetic pathways. Importantly, cell-free reactions can combine the advantages of chemical engineering with metabolic engineering, through the direct addition of co-factors, substrates and chemicals -including those that are

OPEN ACCESS

Edited by:

Jian Li,

ShanghaiTech University, China

Reviewed by:

Lei Kai,

Jiangsu Normal University, China

Chris John Myers,

The University of Utah, United States

${ }^{*}$ Correspondence:

Paul S. Freemont

p.freemont@imperial.ac.uk

Specialty section:

This article was submitted to

Synthetic Biology,

a section of the journal

Frontiers in Bioengineering and

Biotechnology

Received: 10 March 2020

Accepted: 08 April 2020

Published: 12 May 2020

Citation:

Kelwick RJR, Webb AJ and

Freemont PS (2020) Biological

Materials: The Next Frontier

for Cell-Free Synthetic Biology.

Front. Bioeng. Biotechnol. 8:399.

doi: 10.3389/fbioe.2020.00399 cytotoxic. Cell-free synthetic biology is also amenable to automatable design cycles through which an array of biological materials and their underpinning biosynthetic pathways can be tested and optimized in parallel. Whilst challenges still remain, recent convergences between the materials sciences and these advancements in cell-free synthetic biology enable new frontiers for materials research.

Keywords: cell-free synthetic biology, biological materials, biomaterials, biomimetics, metabolic engineering

\section{INTRODUCTION}

We live in a material world (Callén Moreu and López Gómez, 2019). There are more than five trillion plastic pieces in the world's oceans (Eriksen et al., 2014), an estimated 15 billion trees are cut down each year (Crowther et al., 2015) and global natural fiber production is estimated to have already exceeded 30 million tons per annum (Townsend and Sette, 2016). Clearly, the mass production, processing and disposal of an array of materials has significantly shaped the global ecosystem. Whilst we continue to approach irreversible climate change (Lenton et al., 2019), it is of increasing importance that positive advances in the materials sciences are balanced against any negative environmental consequences that relate to material consumption. Arguably, these challenges warrant significant shifts in the manufacturing paradigm, from global mass production to local, sustainable and personalized manufacturing strategies ( $\mathrm{Hu}, 2013$; Stock and Seliger, 2016; Kleer and Piller, 2019). Likewise, instead of the chemical industries, the next generation of materials may come through developments in synthetic biology, sustainable biotechnology and the burgeoning bioeconomy (Le Feuvre and Scrutton, 2018; Philp, 2018; Freemont, 2019; French, 2019).

The field of synthetic biology has emerged over the last twenty years into a highly dynamic community of interdisciplinary researchers and societal stakeholders, that are working toward the 
responsible development and implementation of cutting-edge biotechnologies (Cameron et al., 2014; El Karoui et al., 2019; Lai et al., 2019). Synthetic biology combines knowledge across numerous scientific disciplines including molecular biology, biochemistry, biophysics and the social sciences, whilst also integrating them within an engineering design framework (Anderson et al., 2019; Trump et al., 2019). Ultimately, the synthetic biology approach is geared toward the rational engineering or repurposing of biological parts, devices and systems into solutions that can help address societal challenges (Ausländer et al., 2017). Synthetic biologists envision a broad application space for the field and anticipate positive societal impacts in medical technologies (Pardee, 2018; Hicks et al., 2020) (e.g., biosensors and therapeutics), food security and sustainable energy (Russo et al., 2019; Roell and Zurbriggen, 2020) (e.g., biofuels and synthetic photosynthesis), bioremediation (Dvořák et al., 2017; Wan et al., 2019) (e.g., pollution monitoring and sequestration), education (Kelwick et al., 2015a; Huang et al., 2018; Dy et al., 2019) (e.g., iGEM competition) and biomanufacturing (Le Feuvre and Scrutton, 2018; Choi K.R. et al., 2019; Gilbert and Ellis, 2019; Roberts et al., 2019) (e.g., fine chemicals and materials production).

However, biological systems are highly complex and initial attempts at engineering biological systems to fulfill specific application goals, are often only partially successful. To help overcome these challenges, synthetic biology employs the concept of the design-cycle, through which biotechnologies are iteratively designed, built and tested (Arpino et al., 2013; Church et al., 2014; Kelwick et al., 2014). Learning how to improve a biological system may require multiple attempts, which could be made easier by more rapid and systematic workflows. One potential solution is to utilize cell-free synthetic biology for rapid prototyping (Moore et al., 2017b; Kelwick et al., 2018). Typically, cellfree reactions make use of isolated cellular components and machinery (e.g., ribosomes and recombinant proteins), rather than live whole-cells. Whilst, some cell-free reaction components may be cell-derived (e.g., cell extracts), once prepared, cellfree workflows can be completed within hours (Chappell et al., 2013). In contrast, typical whole-cell experiments may involve several days or weeks of delays that are associated with plasmid cloning, transformation and cell growth (Sun et al., 2014). Furthermore, cell-free reactions are accessible and can combine the advantages of chemical engineering with metabolic engineering, through the direct addition of enzyme co-factors, substrates and chemicals - including those that are cytotoxic (Dudley et al., 2015; Karim and Jewett, 2016; Kay and Jewett, 2020). These advantages are increasingly being exploited for cell-free applications including biopart prototyping, cell-free metabolic engineering, medical or environmental biosensors and on-demand therapeutics production (Kightlinger et al., 2019; Silverman et al., 2019). Based upon an expanding repertoire of examples in the literature, we envision that biological materials and bio-functionalized smart materials are the next frontier for cell-free synthetic biology (Table 1). To this end, this review will introduce key concepts and recent developments in cellfree synthetic biology, with a focus on examples relevant to the materials sciences. Examples will be given of industrially and societally important biological materials that have been generated using cell-free synthetic biology. Cell-free synthetic biology can also be utilized to bio-functionalize materials, which may further enable the emergence of new types of smart materials. This review will also explore future trends and challenges in cell-free synthetic biology and speculate on their potential impact on biological materials of the future.

\section{CELL-FREE SYNTHETIC BIOLOGY REACTION FORMATS AND STRATEGIES}

Cell-free synthetic biology is a broad term that encompasses many different in vitro biotechnologies. Broadly, the term cell-free synthetic biology refers to different methods and technologies for engineering or using biological processes outside of a cell. For example, cell-free protein synthesis reactions enable the production of proteins within biochemical reactions. Thus, cell-free reactions typically make use of isolated cellular components (e.g., recombinant proteins) and/or cell extracts, rather than live whole-cells. In the context of this review four commonly used cell-free reaction formats will be discussed (Figure 1). We describe these cell-free reaction formats as either (i) recombinant enzyme-based, (ii) protein synthesis using recombinant elements (PURE)-based cell-free protein synthesis, (iii) wildtype and/or engineered cell extract biotransformation or (iv) cell extract-based cell-free protein synthesis.

Recombinant enzyme-based reaction formats utilize purified enzymes, along with any required co-factors and pathway substrates, to produce fine chemicals, polymer monomers or other molecules of interest. The PURE-based cell-free protein synthesis format reconstitutes the transcription and translation machinery from Escherichia coli using purified histidine (His)tagged proteins (Shimizu et al., 2001, 2005). In this reaction format, the exact components are known, including the cofactors, substrates and energy mixes. Since PURE reaction components are known they can be standardized and rationally optimized. However, PURE cell-free reactions typically produce lower protein yields than cell-free protein synthesis reactions that use E. coli extracts (Shimizu et al., 2005). The third cellfree reaction format uses cell extracts from lysed wildtype and/or engineered cells, which can be mixed together along with relevant required enzyme co-factors and substrates to form multicomponent biosynthetic pathways. Finally, the last format, cell extract-based cell-free protein synthesis (CFPS), uses the transcription and translation machinery from lysed cells, along with added co-factors and energy mixes to produce proteins in vitro. Cellular extract-based cell-free reactions use the host cells native transcription and translation machinery as well as other metabolic components, including energy providing enzymes such as those involved in glycolysis and the Krebs cycle, which are released when the cells are lysed either mechanically (French pressure cell press), by sonication or osmotically (Gregorio et al., 2019). These reactions were originally developed as experimental tools to enable the fundamental understanding of aspects of cellular biochemistry, molecular biology and in vitro production of various proteins of interest (Gagoski et al., 2016). A range of 
TABLE 1 | Cell-free strategies for biological material biomanufacturing or material bio-functionalization.

\begin{tabular}{|c|c|c|c|}
\hline Cell-free reaction format & Material & Application & References \\
\hline \multirow[t]{2}{*}{ Recombinant enzymes } & Polyhydroxyalkanoates (PHAs) & Biopolymer production & $\begin{array}{l}\text { Thomson et al., 2009; Han et al., 2011; Tomizawa } \\
\text { et al., 2012; Opgenorth et al., } 2016\end{array}$ \\
\hline & Lactic acid & Platform material for polymer production & Kopp et al., 2019 \\
\hline \multirow[t]{5}{*}{ Cell extract biotransformation } & Bio-cellulose & Bio-cellulose production & Ullah et al., 2015 \\
\hline & Chitin & Chitin synthesis & Jaworski et al., 1963 \\
\hline & Poly-3-hydroxybutyrate [P(3HB)] & Optimizing PHAs biopolymer production & Kelwick et al., 2018 \\
\hline & Gold nanoparticles (AuNPs) & Medical and industrial & Chauhan et al., 2011; Krishnan et al., 2016 \\
\hline & Silver nanoparticles (AgNPs) & Nanobiotechnology, therapeutic development & Costa Silva et al., 2017 \\
\hline \multirow[t]{15}{*}{ Cell-free protein synthesis } & Bacteriophages & De novo synthesis and phage engineering & Garamella et al., 2016; Rustad et al., 2018 \\
\hline & Chitin & Chitinase expression & Endoh et al., 2006 \\
\hline & Clay microgels & Protein production & Jiao et al., 2018 \\
\hline & DNA hydrogels/Protein-producing gels (P-gel) & Protein production & Park et al., 2009a; Ruiz et al., 2012 \\
\hline & Elastin-like polypeptides (ELPs) & Biopolymer with non-canonical amino acids & Martin et al., 2018 \\
\hline & Extracellular vesicles (EVs) & Therapeutics/EV biogenesis research & Shurtleff et al., 2016; García-Manrique et al., 2018 \\
\hline & Freeze-dried pellets & In vitro diagnostics or therapeutic production & Pardee et al., 2016b; Salehi et al., 2016, 2017 \\
\hline & Liposomes and nanodiscs & Membrane protein production, drug discovery or protocell production & $\begin{array}{l}\text { Garamella et al., 2016; Rues et al., 2016; Shinoda } \\
\text { et al., 2016; Contreras-Llano and Tan, 2018; } \\
\text { Gessesse et al., 2018; Dubuc et al., 2019; } \\
\text { Shelby et al., } 2019\end{array}$ \\
\hline & Microfluidic devices (various) & Antibody development and protein microarrays & $\begin{array}{l}\text { Killb et al., 2014; Georgi et al., 2016; } \\
\text { Contreras-Llano and Tan, } 2018\end{array}$ \\
\hline & Microparticles/nanoparticles & On-demand functional biomaterials/therapeutics & Lim et al., 2009; Benítez-Mateos et al., 2018 \\
\hline & Paper & In vitro diagnostics & $\begin{array}{l}\text { Pardee et al., 2014, 2016a; Duyen et al., 2017; } \\
\text { Gräwe et al., 2019; Thavarajah et al., } 2020\end{array}$ \\
\hline & PEG hydrogels & Education & Huang et al., 2018 \\
\hline & Poly-3-hydroxybutyrate (P(3HB)) & Polyhydroxyalkanoates (PHAs) biosynthetic operon prototyping & Kelwick et al., 2018 \\
\hline & Protein biologics & Cancer therapeutics, protein therapeutics & $\begin{array}{l}\text { Zawada et al., 2011; Sullivan et al., 2016; Salehi } \\
\text { et al., 2017; Kightlinger et al., } 2019\end{array}$ \\
\hline & Silk fibroin & Silk fibroin production & Greene et al., 1975; Lizardi et al., 1979 \\
\hline
\end{tabular}




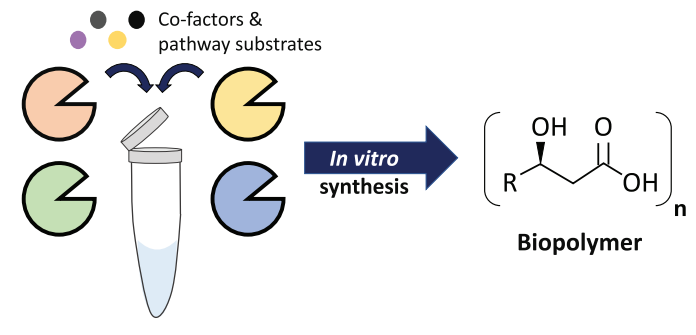

i) Recombinant enzymes

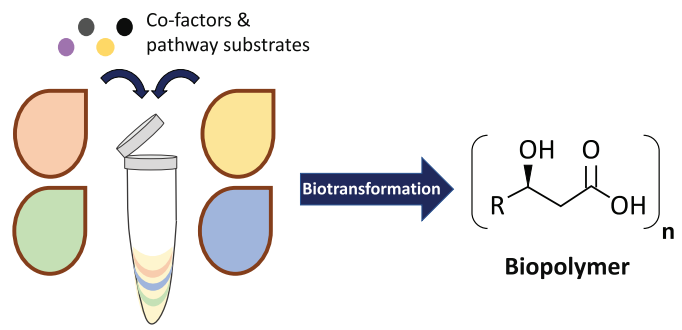

iii) Wildtype and/or engineered cell extracts

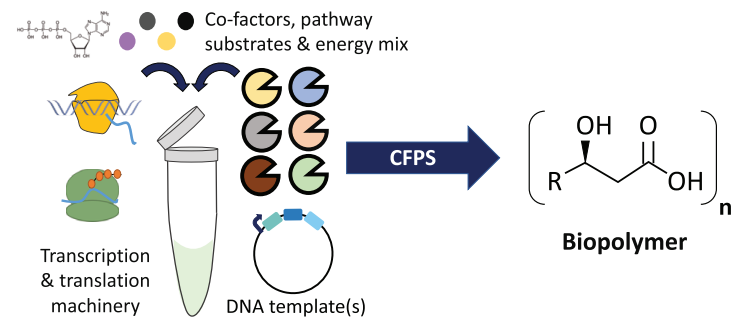

ii) PURE cell-free protein synthesis

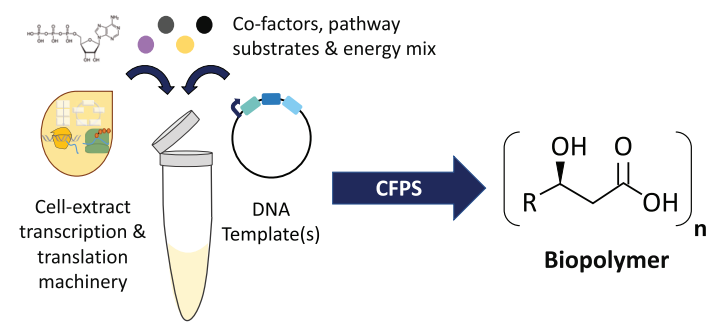

iv) Cell extract cell-free protein synthesis

FIGURE 1 | Cell-free synthetic biology reaction formats and strategies. (i) Recombinant enzymes can be mixed together along with enzyme co-factors and substrates to form biosynthetic pathways. (ii) The PURE cell-free protein synthesis system utilizes reconstituted Escherichia coli transcription and translation machinery, DNA templates, purified enzymes and other factors. (iii) Cell extracts from lysed wildtype or engineered cells can be mixed together along with enzyme co-factors and substrates to form biosynthetic pathways. (iv) Cell extract-based cell-free protein synthesis reactions utilize the transcription and translation machinery within cell lysates, along with exogenously added energy mix components (e.g., amino acids) and DNA templates for in vitro protein production.

different host cells have been used to develop these reactions, including bacteria such as Bacillus subtilis (Kelwick et al., 2016), Streptomyces venezuelae (Moore et al., 2017a; Li et al., 2018) and E. coli (Sun et al., 2013) as well as insect (Ezure et al., 2006), wheat germ (Harbers, 2014), yeast (Hodgman and Jewett, 2013; Aw and Polizzi, 2019), protozoans such as Leishmania tarentolae (Mureev et al., 2009; Kovtun et al., 2010, 2011) and mammalian cells (Weber et al., 1975; Martin et al., 2017).

It is important to note that these different cell-free reaction formats are not mutually exclusive and can be combined together. Recombinant enzymes or small molecule substrates can also be added into cell-free protein synthesis reactions to complete biosynthetic pathways, or to use exogenous chemistries within the reaction. It is this flexibility that we envision being particularly useful in terms of exploring how cell-free reactions could create novel types of biological materials or bio-functionalized smart materials. In the following sections we discuss exemplars where cell-free synthetic reactions have been utilized to prototype, manufacture or bio-functionalize, biological materials (Table 1).

\section{CELL-FREE STRATEGIES FOR SUSTAINABLE MATERIALS BIOMANUFACTURING}

Living cells and organisms have evolved highly complex enzymes and metabolic processes that generate extremely diverse biochemistries. Exploring these natural biochemistries may lead to important foundational advances in our understanding of natural product synthesis. Foundational discoveries in functional genomics, cellular metabolism and natural product synthesis are also important, because they might inspire novel biosynthetic pathway designs for biological materials production. In synthetic biology, cell-free metabolic engineering (CF-ME) approaches can reconstitute entire biosynthetic pathways using either cell extracts from diverse species, engineered cells and/or cellfree synthesized recombinant enzymes (Karim and Jewett, 2018; Martin et al., 2018; Yim et al., 2019; Bowie et al., 2020) (Figure 1). Also, cell-free protein synthesis and cell extract biotransformation reactions can be combined to create more complex cell-free reactions (Karim and Jewett, 2018; Kelwick et al., 2018). Another important advantage in using cell-free approaches is that pathway reaction bottlenecks can be identified, through the direct addition of the required recombinant enzymes, enzyme co-factors or chemical substrates needed for each stage of a biosynthetic pathway (Dudley et al., 2015). Increasingly sophisticated combinatorial CF-ME strategies, together with high-throughput automation, deep data omics and design of experiments (DoE) approaches to cellfree reaction optimization have been deployed (Caschera et al., 2018; Jiang et al., 2018; Dopp et al., 2019). These advancements have considerably improved the feasibility of refactoring and optimizing fine chemical or natural product biosynthetic pathways within short timeframes (Dudley et al., 2015; Korman et al., 2017; Moore et al., 2017a; Wilding et al., 2018).

Cell-free synthetic biology approaches have also been directed toward the de novo bioproduction of biological materials, including biopolymers or their monomers, cellulosic materials and nanoparticles (Table 1). However, the maximum cell-free 
bioproduction yields or reaction efficiencies of several reported materials were generally low or unspecified. Examples of cell-free produced materials and their reported maximum production yields and reaction efficiencies include bio-cellulose (3.726 $\pm 0.05 \mathrm{~g} / \mathrm{L} ; 57.68 \%)$ (Ullah et al., 2015), chitin (yields not stated) (Jaworski et al., 1963; Endoh et al., 2006), lactic acid (6.6 $\pm 0.1 \mathrm{mM} ; 47.4 \pm 3.9 \%$ ) (Kopp et al., 2019), gold nanoparticles (yields not stated) (Chauhan et al., 2011; Krishnan et al., 2016), (R)-3-hydroxybutyrate-CoA (32.87 $\pm 6.58 \mu \mathrm{M})$ (Kelwick et al., 2018), silver nanoparticles (yields not specified) (Costa Silva et al., 2017) and silk fibroin (yields not specified) (Greene et al., 1975; Lizardi et al., 1979). Poor cell-free production yields and efficiencies can be due to a variety of factors including rapid depletion of reaction energy mix components (e.g., ATP, amino acids), the formation of inhibitory waste products (e.g., inorganic phosphates) or unwanted side reactions that divert reaction fluxes away from desirable pathways (Caschera and Noireaux, 2014). Because of these limitations, cell-free synthetic biology may not be an ideal production method for some biological materials. Nevertheless, whilst actual cell-free material production yields can be relatively low, these approaches are still beneficial for prototyping different biosynthetic pathways, substrates or reaction conditions to boost both in vitro and whole-cell production yields. An exemplar is the use of cell-free assays to characterize polyhydroxyalkanoates (PHAs) biosynthetic pathways from phaCAB operons that also enhanced in vivo PHAs production (Kelwick et al., 2018). Furthermore, the same study also demonstrated that the cell-extract biotransformation of whey permeate into 3hydroxybutyrate $(3 \mathrm{HB})$, could be simultaneously coupled with the cell-free protein synthesis of a potential Acetyl-CoA recycling enzyme (Kelwick et al., 2018). Thus, highlighting that combinatorial cell-free reaction formats can be a useful strategy for bioplastic pathway prototyping and optimization.

Interestingly, in some cases, cell-free bioproduction may actually be a more desirable manufacturing route. For instance, several in vitro gold or silver nanoparticle production studies reported desirable nanoparticle characteristics (e.g., size/zeta potential) and/or easier purification protocols within cell-free bioproduction reactions than whole-cell production methods (Krishnan et al., 2016; Costa Silva et al., 2017). Cell-free bioproduction can also be carried out at industrially relevant scales, as illustrated by Sutro biopharma who have developed a highly scalable good manufacturing practices (GMP)-compliant cell-free protein synthesis platform, for producing therapeutic proteins within $100 \mathrm{~L}$ bioreactor reaction volumes (Zawada et al., 2011). For cell-free materials production, a highly efficient synthetic biochemistry module was developed to convert glucose into bio-based chemicals, including the PHA bioplastic monomer polyhydroxybutyrate (PHB) (Opgenorth et al., 2016). To achieve this, purified recombinant enzymes were used to reconstitute core elements of the pentose, bifido, glycolysis and $\mathrm{PHB}$ pathways (Opgenorth et al., 2016). Cell-free PHB production yields ( $40 \mathrm{~g} / \mathrm{L})$ and efficiencies (90\%) were impressive and are promisingly close to industrially attractive scales (Opgenorth et al., 2016). These improvements in $\mathrm{PHB}$ production are also welcome since $\mathrm{PHB}$, as well as other PHAs biopolymers, are biodegradable and can potentially be used as 'drop-in' replacements for oilderived plastics (e.g., food packaging) or as biomaterials for tissue engineering (Choi S.Y. et al., 2019; Tarrahi et al., 2020). PHAs are also an interesting example because of their industrial importance and the diversity of cell-free strategies that have been applied to PHAs research (Table 1). Building upon these examples, CFME approaches could be used to explore a greater diversity of PHAs biopolymers given that PHA biopolymers can be composed of a variety of different wildtype and/or synthetic monomers ( $\sim 160$ different monomers exist) to create complex co-polymers, with an array of material characteristics (Choi S.Y. et al., 2019). Future cell-free synthetic biology explorations of PHAs are likely to unlock novel PHAs biopolymers with unique characteristics (Chen and Hajnal, 2015) and therefore, accelerate bioplastic materials development.

Microbial (in vivo) PHAs production has been commercially manufactured at industrial scales over the last several decades. Unfortunately, the commercial impact of PHA-based bioplastics has been historically prohibited by their higher production costs than oil-derived plastics (Chen et al., 2020). However, more efficient PHAs production processes have been devised through the rational design of phaCAB biosynthetic pathways (Hiroe et al., 2012; Kelwick et al., 2015b; Li et al., 2016; Tao et al., 2017; Zhang X. et al., 2019), key metabolite recycling processes (e.g., Acetyl-CoA) (Matsumoto et al., 2013; Beckers et al., 2016), alternative microbial production hosts (e.g., Halomonas sp., Tan et al., 2011) and the use of industrially sourced, low-cost feedstocks (e.g., whey permeate) (Wong and Lee, 1998; Ahn et al., 2000; Kim, 2000; Nikel et al., 2006; Cui et al., 2016; Nielsen et al., 2017). Interestingly, several of these microbial PHAs production strategies are also compatible with cell-free synthetic biology reactions. In particular, using locally sourced, low-cost feedstocks (e.g., whey permeate) may help to make cell-extract based PHAs production more economically viable (Kelwick et al., 2018). A similar approach has already been piloted for cell-free lactic acid production from spent coffee grounds (Kopp et al., 2019) and could become a generalized strategy for sustainable cell-free materials bioproduction (Figure 2). We would argue that combining cell-free extracts with local feedstocks enables immediate access to highly diverse cellular biochemistries and low-cost substrates (e.g., waste feedstocks), that could potentially be used for the sustainable biomanufacturing of a diverse array of biological materials (Yan and Fong, 2015; Le Feuvre and Scrutton, 2018). Furthermore, just as lyophilized cell-free reactions enable the on-demand production of biotherapeutics (Pardee et al., 2016b), we likewise envision that cell-free reactions might one day lead to rapid and distributed, on-demand biological materials production or bio-functionalization.

\section{CELL-FREE MATERIAL BIO-FUNCTIONALIZATION AND BIOMIMETICS}

Cell-free systems are still being applied to understand the foundational principles and molecular mechanisms of transcription and translation (Hecht et al., 2017; Borkowski 


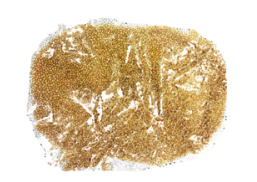

Whey permeate

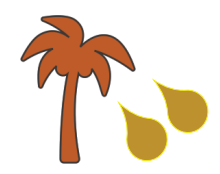

Palm oil mill effluent
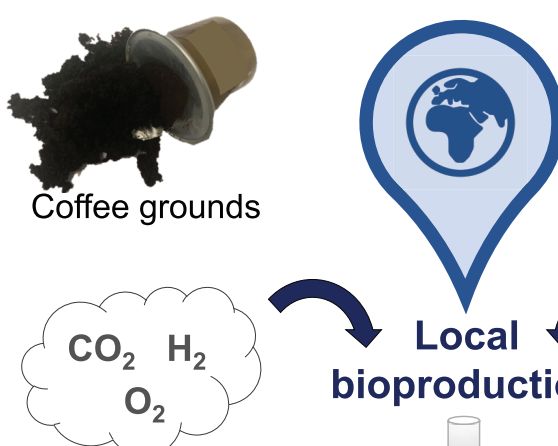

Gaseous substrates

\section{Exemplar local feedstocks}

\section{bioproduction}

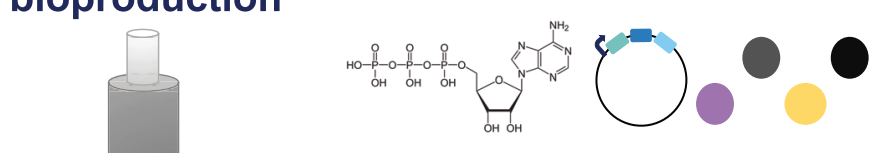

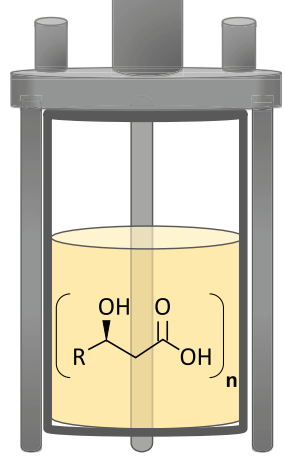

Cell-free reaction components

FIGURE 2 | Sustainable cell-free biomanufacturing of biological materials. Schematic depicts the local, on-demand cell-free mediated, biomanufacturing of biological materials. Local feedstocks can potentially be utilized as replacements for expensive reaction energy mix components, or to provide the enzymatic co-factors and biosynthetic pathway substrates that are required to produce biological materials of interest.

et al., 2018). Unlocking these principles can also potentially identify novel strategies to enhance in vitro protein production, which continues to be a core application for cell-free synthetic biology (Gagoski et al., 2016; Khambhati et al., 2019). Simplified or improved cell-free methodologies (Sun et al., 2013; Kwon and Jewett, 2015; Krinsky et al., 2016; Katsura et al., 2017; Lavickova and Maerkl, 2019), coupled with lower-cost and rationally optimized cell-free reaction energy mixes (Cai et al., 2015), has enabled the implementation of in vitro therapeutic protein production at industrial scales (Ogonah et al., 2017; Garenne and Noireaux, 2019). Interestingly, the integration of cell-free reactions within materials can also enhance cell-free protein synthesis yields. For instance, the Luo group has developed the protein-producing gel (P-gel) platform, which integrates protein-producing cell-free reactions within enzyme-catalyzed, 3D DNA hydrogel matrices (Park et al., 2009a). P-gels have been used to produce a panel of model proteins including green fluorescent protein (GFP), chloramphenicol acetyltransferase (CAT) and Renilla reniformis luciferase protein (Park et al., 2009a,b). Optimized P-gels reportedly generated between 1.87 and $5 \mathrm{mg} / \mathrm{ml}^{-1}$ of functional luciferase protein, which was significantly higher ( $>90$-fold) than comparative, standard liquid-format cell-free reactions (Park et al., 2009a,b). However, the authors compared P-gels against linear DNA templates within standard, liquid-format cell-free reactions. In comparison to plasmid DNA, linear DNA fragments can be relatively unstable in cell-free reactions and this instability can result in relatively low cell-free protein production yields (Chappell et al., 2013; Sun et al., 2014). Nevertheless, the P-gel platform is potentially a flexible and versatile platform for cell-free protein production. Furthermore, P-gel droplets can also be rapidly fabricated using microfluidics - thus making scale-up more feasible (Ruiz et al., 2012). In a separate study, a microfluidic fabrication strategy has been developed to embed cell-free protein synthesis reactions within clay microgels that could produce $>1 \mathrm{mg} / \mathrm{ml}$ of GFP protein (Jiao et al., 2018). Importantly, P-gels and clay microgels illustrate that the cell-free functionalization of materials can lead to novel approaches for protein biomanufacturing.

Combining cell-free synthetic biology with materials can also be important for other applications. For example, by combining the cell-free protein synthesis of membrane proteins with liposomes or nanodiscs can potentially facilitate the production and stable integration of membrane proteins within lipid bilayers - thus enabling structure-function studies or drug discovery applications (Shinoda et al., 2016; Gessesse et al., 2018; Shelby et al., 2019). In a separate study, the Schekman group recreated aspects of exosome biogenesis in vitro, by using cell-free reactions to examine exosome membrane protein 
topology and exosome-associated miRNA sorting (Shurtleff et al., 2016). These cell-free approaches also enable directed membrane functionalization - potentially leading to rationally engineered protocells and designer exosomes. Combining cell-free synthetic biology with materials has led to the bottom-up engineering of biomimetics, including synthetic protocells (Shin and Noireaux, 2012; Huang et al., 2013; Garamella et al., 2016; Dubuc et al., 2019; Yue et al., 2019), entire phages (Rustad et al., 2018) and more recently, a partially self-replicating in vitro translation system was reported that functions by activating a $116 \mathrm{~kb}$ genome and is an important step toward a living, synthetic cell (Libicher et al., 2020).

\section{CELL-FREE SYNTHETIC BIOLOGY ENABLED SMART MATERIALS}

Cell-free synthetic biology reactions also enable smart materials and biosensor applications. Cell-free synthetic biology reactions can be programmed with plasmid-encoded gene circuits, lyophilized and embedded within paper (Pardee et al., 2014, 2016a; Smith and Berkheimer, 2014; Pardee, 2018), as well as potentially other materials such P-gels or clay microgels. Cellfree paper-based biosensors can be activated, post-lyophilization, using water or liquid samples and have been shown to maintain activity even after several months of storage at room temperature (Pardee et al., 2014; Smith and Berkheimer, 2014). Once activated, these paper-based cell-free reactions enable in vitro biosensor applications where these cell-free reactions are programmed to generate detectable signal outputs in response to the presence of relevant molecules (e.g., Mercury) or disease biomarkers (Lee and Kim, 2019; Silverman et al., 2019). Beneficially, these cell-free smart materials also provide greater flexibilities in terms of their usage beyond the laboratory and outside in the field (Pardee et al., 2016a,b). The complexity of synthetic biology genetic circuits and the strategies used to devise them has increased significantly in recent years (Nielsen et al., 2016; Grunberg and Del Vecchio, 2020). This has resulted in the development of an array of cell-free compatible genetic circuits that incorporate a variety of different regulatory elements that are applicable to different biosensing applications. For example, cell-free compatible gene networks can be transcription-based such that the presence of a small molecule induces reporter gene expression, through binding to, and activation or repression of, a transcriptional regulator. These types of transcriptional gene circuits have been used to develop cell-free biosensors for detecting heavy metals (Gräwe et al., 2019; Gupta et al., 2019), a date-rape drug (Gräwe et al., 2019), metabolites (Voyvodic et al., 2019) and quorum sensing molecules from Pseudomonas aeruginosa-infected respiratory samples (Wen et al., 2017). Small molecules can also regulate transcription by binding to endogenous or engineered RNA aptamer-regions within $5^{\prime}$ untranslated (UTR) mRNA regions - termed riboswitches. Small molecule binding to the riboswitch facilitates the emergence of stable RNA structures that permit continued reporter gene transcription. Small molecules can regulate translation via a different mechanism, whereby binding of the small molecule to the riboswitch influences the mRNA structure such that it occludes ribosome binding and downstream translation (Nahvi et al., 2002). Utilizing these principles a cell-free biosensor was developed that exploits a riboswitch to detect environmental fluoride (Thavarajah et al., 2020). Cell-free biosensors can also utilize toeholds to detect RNAs (e.g., viral RNA). Essentially, toehold aptamers function in a similar way to riboswitches except that the presence of a complementary RNA is responsible for a conformational change in the mRNA that enables ribosome access and reporter protein translation (Figure 3). Engineered cell-free toehold biosensors can also differentiate between different Ebola (Pardee et al., 2014) and Zika (Pardee et al., 2016a) strains. Conceivably, RNA aptamer-based approaches could be adapted to detect Coronaviruses such as SARS-CoV and 2019 n-CoV (Ahn et al., 2009). Indeed, the 2020 COVID19 pandemic might be a catalyst for the development of cellfree viral biosensors and the accompanying clinical studies that will be required for comparative testing against existing technologies (e.g., quantitative reverse transcription polymerase chain reaction, RT-qPCR) (Liu et al., 2020). Post-translational cell-free biosensors have also been developed to detect glucose. In this example, cell-free protein synthesis was used to produce fusion protein pairs that elicit changes in Fluorescence Resonance Energy Transfer (FRET) signals in response to bound glucose (Pardee et al., 2014). Furthermore, purified fusion proteins can also enable other types of smart material applications. For instance, Wagner et al. (2019) developed information-processing materials that function by using protease-based signal-amplifying cascades, that integrate both proteolytic activities and ligandreceptor sensing within its logic circuits. As an exemplar, the same authors reported on the development of smart materials, inspired by synthetic biology logic circuits, that can detect novobiocin antibiotics (Wagner et al., 2019). These, as well as many other transcriptional and translational regulatory mechanisms can be combined into highly complex cell-free executable circuit designs (Jeong et al., 2019). Therefore, it is conceivable that these studies might inspire future efforts to embed cell-free executable logic circuits within a broad array of synthetic biology-based smart materials.

\section{AUTOMATED DESIGN-CYCLES FOR CELL-FREE BIOLOGICAL MATERIALS}

An important future trend in synthetic biology is the maturation of rational, engineering-led strategies for designing and implementing complex biological systems. Essentially, the field of synthetic biology envisions a future where modelguided, forward-engineering strategies will be routinely used to iterate design-build-test-learn cycles toward the final biotechnology production and application (Kelwick et al., 2014; Bultelle et al., 2016; Misirli et al., 2019). However, the scale of experiments needed to realize this vision may require continued advancements in synthetic biology machine-learning strategies, coupled with automation equipment (e.g., liquid handling robots) (Bultelle et al., 2016; Rajakumar et al., 2019). Indeed, automation capabilities can greatly expand the scale, 


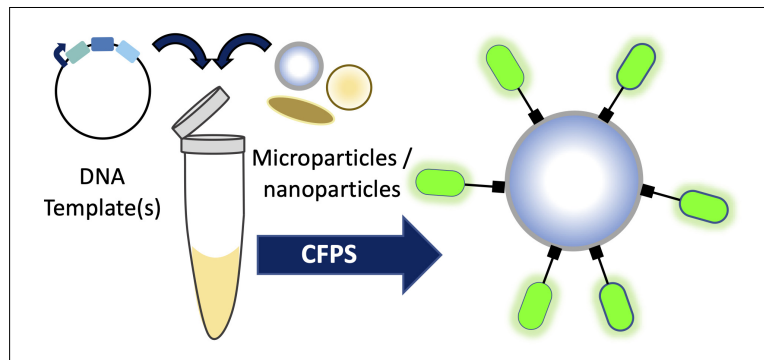

Microparticles \& nanoparticles

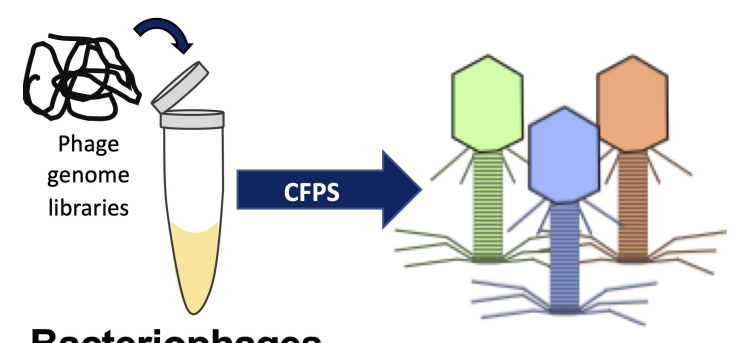

Bacteriophages

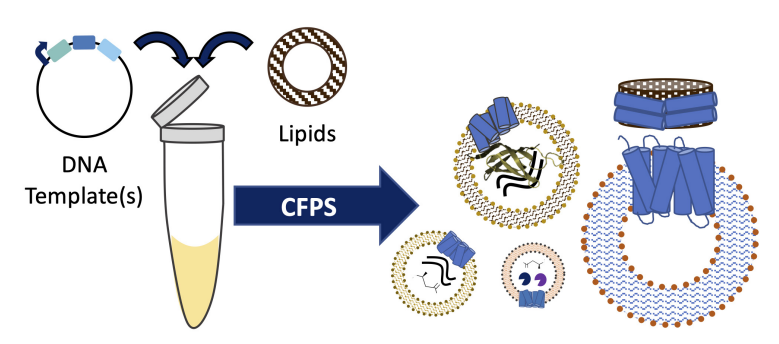

Exosomes, liposomes \& nanodiscs
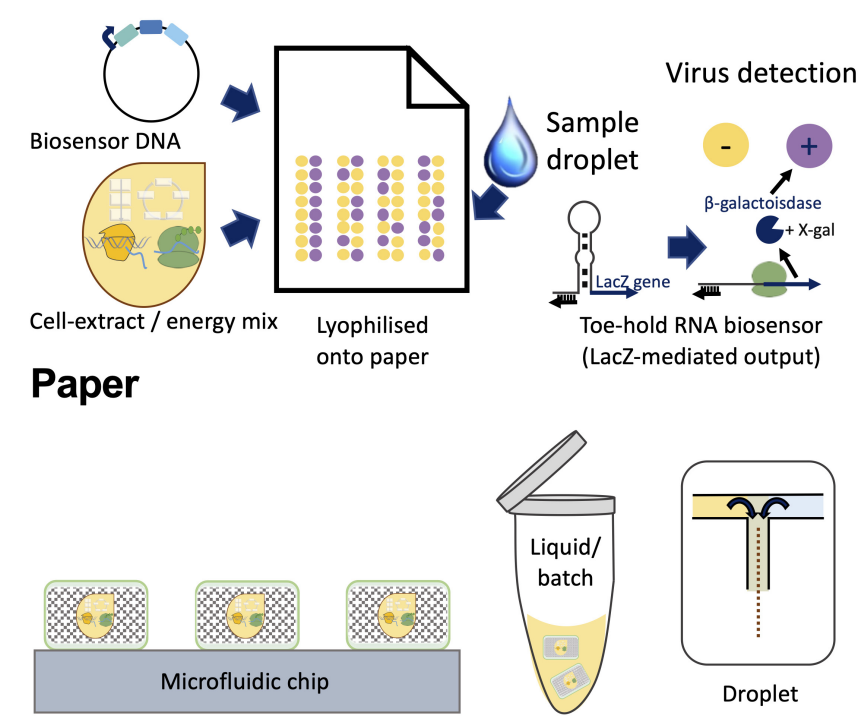

Hydrogels \& clay microgels
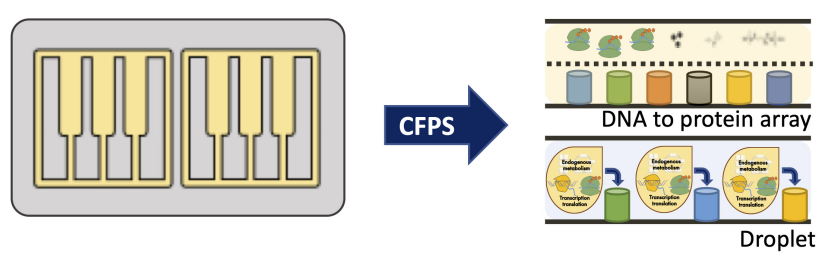

Microfluidic surface display

FIGURE 3 | Cell-free synthetic biology-based material functionalization. Schematic depicts examples of materials that have been bio-functionalized using cell-free protein synthesis (CFPS) reactions.

sophistication and scope of synthetic biology design cycles (Kelwick et al., 2014; Carbonell et al., 2019; El Karoui et al., 2019; Hillson et al., 2019; Jessop-Fabre and Sonnenschein, 2019). Co-ordinated efforts toward improving inter-laboratory data reproducibility, standardizing experimental metrology and an emphasis on industrially scalable biotechnology are also driving the adoption of automation in synthetic biology workflows (Kelly et al., 2009; Beal et al., 2016, 2018a,b; de Lorenzo and Schmidt, 2018; Carbonell et al., 2019; Exley et al., 2019). In a broader sense, automation is also becoming more accessible through reductions in gene synthesis costs (Carlson, 2014), advancements in automated DNA assembly protocols (Kanigowska et al., 2016; Rajakumar et al., 2019; Storch et al., 2019; Walsh et al., 2019), rapid mass spectrometry of complex biological samples (Gowers et al., 2019; Miguez et al., 2019; O’Kane et al., 2019) and through the emergence of academic biofoundries (Chambers et al., 2016; Hillson et al., 2019).

Cell-free prototyping strategies can be readily integrated into design-cycles, including those applications that are intended to be functional in living cells (in vivo). Several studies have described comparability between DNA regulatory elements and genetic circuits tested in vitro (cell-free) and in vivo (wholecells) across several model (e.g., E. coli, Bacillus subtilis) (Chappell et al., 2013; Sun et al., 2014; Kelwick et al., 2016) and nonmodel (e.g., Bacillus megaterium, Vibrio natriegens) (Failmezger et al., 2018; Moore et al., 2018) organisms. Thus, cell-free rapid prototyping strategies can also be applied to speed up the development of in vivo (whole-cell) applications. Cell-free workflows are also amenable to automation. Indeed, several studies have successfully utilized acoustic liquid handling robots to rapidly setup large-scale, low-volume $(\leq 10 \mu \mathrm{l})$ prototyping cell-free reactions in a 384 well plate format (Moore et al., 2018; Kopniczky et al., 2020). Microfluidic (Swank et al., 2019), droplet array (Zhang Y. et al., 2019) or multiplex (Yim et al., 2019) strategies have also been used to enable high-throughput cell-free experiments. These approaches enable the testing of large numbers of regulatory elements or enzymes, which could potentially inform material biosynthetic pathway optimization. Conceivably, cell-free optimized material biosynthetic pathways could also be implemented within in vivo production strategies 
(e.g., microbial cell factories). These data sets also enable accompanying quantitative modeling that can potentially predict unknown model parameters, such as transcription factor binding affinities or cell-free energy utilization (Bujara and Panke, 2012; Moore et al., 2018). These data can potentially be entered into biopart data repositories (Ham et al., 2012; Bultelle et al., 2016; McLaughlin et al., 2018) for use in machine learning-enhanced design of experiments (DoE) approaches, to speed up materials development (Liu et al., 2017; Exley et al., 2019; Madsen et al., 2019). High-throughput cell-free experiments can also tease apart where cell-free reactions are fundamentally different to native intracellular environments. Molecular crowding, metabolic fluxes, co-factor regeneration rates and other biophysiochemical characteristics may all differ between cell-free reactions and in vivo (whole-cell) contexts. Also, cell extract processing breaks down cellular organelles and other intracellular compartments, thus perturbing native biomolecule localization. Yet, despite these potential limitations complex genetic circuits (e.g., oscillators), that are functional in vivo, have been prototyped using cell-free forward-engineering design cycles (Niederholtmeyer et al., 2015). This review has also explored several other examples where cell-free approaches have been used to produce or bio-functionalize materials (Table 1). It is therefore conceivable, that cell-free synthetic biology design-cycles may strengthen future efforts to accelerate the development of an array of bio-functionalized smart materials (Figure 4).

\section{SUMMARY AND OUTLOOK}

In an era of extreme climate events there is an increasing global consensus to collectively implement more sustainable and carbon-neutral policies (Gills and Morgan, 2019). However, there continues to be an insatiable global demand for materials and the natural resources that are used to manufacture them. These activities have, however, negatively impacted the global ecosystem through for example deforestation, industrial pollution and biodiversity destruction. To partially address some of these challenges, there is increasing support for more locally based bioeconomies underpinned by sustainable practices. Cell-free biomanufacturing could have an important role in the emerging bioeconomy by enabling biological materials to be produced locally, on-demand and more sustainably from waste feedstocks (e.g., whey permeate). Furthermore, centrally produced cell-free reaction components can be lyophilized and then distributed to different geographical locations (Pardee et al., 2016b). Once distributed, these cell-free reactions could

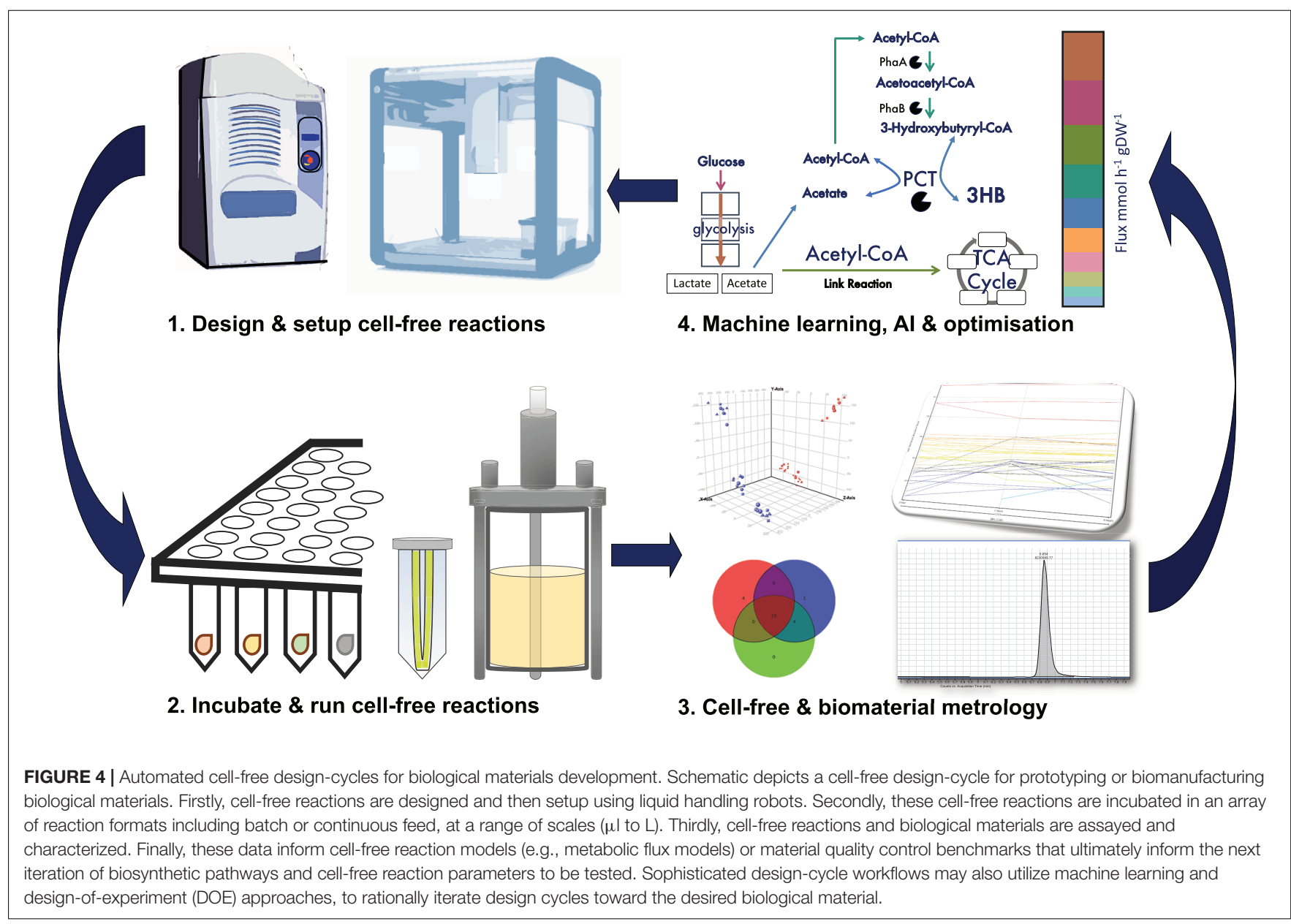


potentially make use of highly customized DNA-encoded biosynthetic operons to produce personalized materials that suit local needs. Conceivably, these cell-free produced biological materials could be fabricated using synthetic biochemistries [e.g., unnatural amino acids (Martin et al., 2018; Des Soye et al., 2019; Gao et al., 2019) and xeno nucleic acids (Glasscock et al., 2016; Hu et al., 2019)], mixed cell extracts from diverse bacterial species (Yim et al., 2019), or de novo biological components [e.g., engineered ribosomes (Caschera et al., 2018; d'Aquino et al., 2020) and rationally designed proteins (Huang et al., 2016; Rolf et al., 2019)]. These synthetic components might confer cell-free produced materials with unique physical characteristics or other attributes that are not typically associated with natural fibers. Likewise, we envision that future cellfree materials will have integrated smart-features including biosensing capabilities, the ability to change material properties in response to specific stimuli or self-healing capabilities when damaged. Such capabilities may require further advancements in cell-free genetic circuits and the methods used to embed them within different materials.

A panoply of recent examples, including those discussed in this review, are indicative that biological materials are the next frontier for cell-free synthetic biology - but challenges remain. A deeper understanding of the compositions and biochemical activities of processed cell extracts and cell-free reactions are needed (Foshag et al., 2018) to mitigate cell-free extract batch variability and increase protein synthesis yields. Compounding these challenges are the need for improved cell-free metrology and cell-free biomanufacturing quality control standards, which are especially important for industrial applications (de Lorenzo and Schmidt, 2018). Equally, the acceptability of cell-free produced biological materials may need to be considered through stakeholder engagement, consumer awareness activities and through, where necessary, the establishment of specialist recycling/waste management infrastructure. The scalability of cell free reactions to industrial manufacturing is also extremely challenging. Despite these challenges, Genomatica, Greenlight Biosciences, Sutro Biopharma, Tierra Biosciences and other companies have already successfully developed scalable cellfree synthetic biology platforms that have at least pilot tested materials production (e.g., Genomatica's cell-free platform produces polymer chemicals including 1,4-butanediol). In addition, the synthetic biology companies Bolt Threads, Spiber, Colorifix, and Ginkgo Bioworks are also working toward a future sustainable fashion industry. Bolt Threads produce spinnable recombinant spider silk in yeast and are also

\section{REFERENCES}

Ahn, D.-G., Jeon, I.-J., Kim, J. D., Song, M.-S., Han, S.-R., Lee, S.-W., et al. (2009). RNA aptamer-based sensitive detection of SARS coronavirus nucleocapsid protein. Analyst 134:1896. doi: 10.1039/b906788d

Ahn, W. S., Park, S. J., and Lee, S. Y. (2000). Production of Poly(3-hydroxybutyrate) by fed-batch culture of recombinant Escherichia coli with a highly concentrated whey solution. Appl. Environ. Microbiol. 66, 3624-3627. doi: 10.1128/aem.66.8. 3624-3627.2000 developing scalable biomanufacturing processes for mushroombased leather. Spiber are also producing recombinant silk, as well as other synthetic protein materials. Both Bolt Threads and Spiber have successfully manufactured pilot batches of clothing products for a future sustainable fashion industry. Colorifix have developed a biological textile dye process that is designed to be less polluting than traditional chemical methods. Meanwhile, Ginkgo Bioworks have made significant investments into their organism-engineering foundry to support an array of manufacturing applications - including the production of materials. Ginkgo Bioworks also occasionally uses cell-free metabolic engineering strategies within its innovation pipelines.

In summary, cell-free synthetic biology is a powerful, highly customizable and promising biotechnology that is beginning to have a positive impact on the industrialization of sustainable materials production. Importantly, synthetic biology companies continue to champion interdisciplinary collaborations with designers and materials scientists as part of the development process. We envision that a continuation of these trends will result in a new frontier for sustainable cell-free materials production and the growing bioeconomy.

\section{AUTHOR CONTRIBUTIONS}

All authors listed have made a substantial, direct and intellectual contribution to the work, and approved it for publication.

\section{FUNDING}

RK was supported by a BBSRC-funded Royal Society of Edinburgh Enterprise Fellowship. AW was supported by the UK Government's Global Challenges Research Fund (GCRF) through the EPSRC grant (EP/P028519/1) as part of the WISER project. We acknowledge the support of Imperial Confidence in Concept (MRC/EPSRC), Imperial College London EPSRC Impact Acceleration Account (EP/R511547/1), EPSRC grant (EP/L011573/1), BBSRC grant (BB/L027852/1), and the Imperial College London CRUK Development Fund.

\section{ACKNOWLEDGMENTS}

We thank colleagues in the Section of Structural and Synthetic Biology, WISER project colleagues and Dr. Amélie Heliot. synthetic biology: a MOOC for an emerging field. Synth. Biol. 4:ysz010. doi: 10.1093/synbio/ysz010

Arpino, J. A. J., Hancock, E. J., Anderson, J., Barahona, M., Stan, G.-B. V., Papachristodoulou, A., et al. (2013). Tuning the dials of synthetic biology. Microbiology 159, 1236-1253. doi: 10.1099/mic.0.067975-0

Ausländer, S., Ausländer, D., and Fussenegger, M. (2017). synthetic biology-the synthesis of biology. Angew. Chemie Int. Ed. 56, 6396-6419. doi: 10.1002/anie. 201609229 
Aw, R., and Polizzi, K. M. (2019). Biosensor-assisted engineering of a high-yield Pichia pastoris cell-free protein synthesis platform. Biotechnol. Bioeng. 116, 656-666. doi: 10.1002/bit.26901

Beal, J., Haddock-Angelli, T., Baldwin, G., Gershater, M., Dwijayanti, A., Storch, M., et al. (2018a). Quantification of bacterial fluorescence using independent calibrants. PLoS One 13:e0199432. doi: 10.1371/journal.pone.0199432

Beal, J., Haddock-Angelli, T., Farny, N., and Rettberg, R. (2018b). Time to get serious about measurement in synthetic biology. Trends Biotechnol. 36, 869871. doi: 10.1016/j.tibtech.2018.05.003

Beal, J., Haddock-Angelli, T., Gershater, M., de Mora, K., Lizarazo, M., Hollenhorst, J., et al. (2016). Reproducibility of fluorescent expression from engineered biological constructs in E. coli. PLoS One 11:e0150182. doi: 10.1371/journal. pone. 0150182

Beckers, V., Poblete-Castro, I., Tomasch, J., and Wittmann, C. (2016). Integrated analysis of gene expression and metabolic fluxes in PHA-producing Pseudomonas putida grown on glycerol. Microb. Cell Fact. 15:73. doi: 10.1186/ s12934-016-0470-2

Benítez-Mateos, A. I., Llarena, I., Sánchez-Iglesias, A., and López-Gallego, F. (2018). Expanding one-pot cell-free protein synthesis and immobilization for on-demand manufacturing of biomaterials. ACS Synth. Biol. 7, 875-884. doi: 10.1021/acssynbio.7b00383

Borkowski, O., Bricio, C., Murgiano, M., Rothschild-Mancinelli, B., Stan, G.-B., and Ellis, T. (2018). Cell-free prediction of protein expression costs for growing cells. Nat. Commun. 9:1457. doi: 10.1038/s41467-018-03970-x

Bowie, J. U., Sherkhanov, S., Korman, T. P., Valliere, M. A., Opgenorth, P. H., and Liu, H. (2020). Synthetic biochemistry: the bio-inspired cell-free approach to commodity chemical production. Trends Biotechnol. doi: 10.1016/j.tibtech. 2019.12.024

Bujara, M., and Panke, S. (2012). In silico assessment of cell-free systems. Biotechnol. Bioeng. 109, 2620-2629. doi: 10.1002/bit.24534

Bultelle, M., de Murieta, I. S., and Kitney, R. (2016). "Introducing SynBIS - the synthetic biology information system," in Proceedings of the IET/SynbiCITE Engineering Biology Conference, Michael Faraday House.

Cai, Q., Hanson, J. A., Steiner, A. R., Tran, C., Masikat, M. R., Chen, R., et al. (2015). A simplified and robust protocol for immunoglobulin expression in $E$ scherichia coli cell-free protein synthesis systems. Biotechnol. Prog. 31, 823-831. doi: $10.1002 /$ btpr.2082

Callén Moreu, B., and López Gómez, D. (2019). Intimate with your junk! A waste management experiment for a material world. Sociol. Rev. 67, 318-339. doi: $10.1177 / 0038026119830318$

Cameron, D. E., Bashor, C. J., and Collins, J. J. (2014). A brief history of synthetic biology. Nat. Rev. Microbiol. 12, 381-390. doi: 10.1038/nrmicro3239

Carbonell, P., Radivojevic, T., and García Martín, H. (2019). Opportunities at the intersection of synthetic biology, machine learning, and automation. ACS Synth. Biol. 8, 1474-1477. doi: 10.1021/acssynbio.8b00540

Carlson, R. (2014). Time for New DNA Sequencing And Synthesis Cost Curves. Available online at: https://synbiobeta.com/time-new-dna-synthesissequencing-cost-curves-rob-carlson/ (accessed February 1, 2020).

Caschera, F., Karim, A. S., Gazzola, G., D’Aquino, A. E., Packard, N. H., and Jewett, M. C. (2018). High-throughput optimization cycle of a cell-free ribosome assembly and protein synthesis system. ACS Synth. Biol. 7, 2841-2853. doi: 10.1021/acssynbio.8b00276

Caschera, F., and Noireaux, V. (2014). Synthesis of $2.3 \mathrm{mg} / \mathrm{ml}$ of protein with an all Escherichia coli cell-free transcription-translation system. Biochimie 99, 162-168. doi: 10.1016/j.biochi.2013.11.025

Chambers, S., Kitney, R., and Freemont, P. (2016). The foundry: the DNA synthesis and construction foundry at imperial college. Biochem. Soc. Trans. 44, 687-688. doi: 10.1042/BST20160007

Chappell, J., Jensen, K., and Freemont, P. S. (2013). Validation of an entirely in vitro approach for rapid prototyping of DNA regulatory elements for synthetic biology. Nucleic Acids Res. 41, 3471-3481. doi: 10.1093/nar/gkt052

Chauhan, A., Zubair, S., Tufail, S., Sherwani, A., Sajid, M., Raman, S. C., et al. (2011). Fungus-mediated biological synthesis of gold nanoparticles: potential in detection of liver cancer. Int. J. Nanomedicine 2305:195. doi: 10.2147/IJN. $\mathrm{S} 23195$

Chen, G.-Q., Chen, X.-Y., Wu, F.-Q., and Chen, J.-C. (2020). Polyhydroxyalkanoates (PHA) toward cost competitiveness and functionality. Adv. Ind. Eng. Polym. Res. 3, 1-7. doi: 10.1016/j.aiepr.2019.11.001
Chen, G.-Q., and Hajnal, I. (2015). The 'PHAome.’. Trends Biotechnol. 33, 559-564. doi: 10.1016/j.tibtech.2015.07.006

Choi, K. R., Jang, W. D., Yang, D., Cho, J. S., Park, D., and Lee, S. Y. (2019). Systems metabolic engineering strategies: integrating systems and synthetic biology with metabolic engineering. Trends Biotechnol. 37, 817-837. doi: 10.1016/j.tibtech. 2019.01.003

Choi, S. Y., Rhie, M. N., Kim, H. T., Joo, J. C., Cho, I. J., Son, J., et al. (2019). Metabolic engineering for the synthesis of polyesters: a 100-year journey from polyhydroxyalkanoates to non-natural microbial polyesters. Metab. Eng. 58, 47-81. doi: 10.1016/j.ymben.2019.05.009

Church, G. M., Elowitz, M. B., Smolke, C. D., Voigt, C. A., and Weiss, R. (2014). Realizing the potential of synthetic biology. Nat. Rev. Mol. Cell Biol. 15, 289-294. doi: 10.1038/nrm3767

Contreras-Llano, L. E., and Tan, C. (2018). High-throughput screening of biomolecules using cell-free gene expression systems. Synth. Biol. 3, 1-13. doi: 10.1093/synbio/ysy012

Costa Silva, L. P., Pinto Oliveira, J., Keijok, W. J., da Silva, A. R., Aguiar, A. R., Guimarães, M. C. C., et al. (2017). Extracellular biosynthesis of silver nanoparticles using the cell-free filtrate of nematophagous fungus duddingtonia flagrans. Int. J. Nanomedicine Volume 12, 6373-6381. doi: 10.2147/IJN.S137703

Crowther, T. W., Glick, H. B., Covey, K. R., Bettigole, C., Maynard, D. S., Thomas, S. M., et al. (2015). Mapping tree density at a global scale. Nature 525, 201-205. doi: 10.1038/nature14967

Cui, Y.-W., Zhang, H.-Y., Lu, P.-F., and Peng, Y.-Z. (2016). Effects of carbon sources on the enrichment of halophilic polyhydroxyalkanoate-storing mixed microbial culture in an aerobic dynamic feeding process. Sci. Rep. 6:30766. doi: $10.1038 /$ srep30766

d'Aquino, A. E., Azim, T., Aleksashin, N. A., Hockenberry, A. J., Krüger, A., and Jewett, M. C. (2020). Mutational characterization and mapping of the 70 S ribosome active site. Nucleic Acids Res. 48, 2777-2789. doi: 10.1093/nar/ gkaa001

de Lorenzo, V., and Schmidt, M. (2018). Biological standards for the knowledgebased bioeconomy: what is at stake. N. Biotechnol. 40, 170-180. doi: 10.1016/j. nbt.2017.05.001

Des Soye, B. J., Gerbasi, V. R., Thomas, P. M., Kelleher, N. L., and Jewett, M. C. (2019). A highly productive, one-pot cell-free protein synthesis platform based on genomically recoded Escherichia coli. Cell Chem. Biol. 26, 1743.e-1754.e. doi: 10.1016/j.chembiol.2019.10.008

Dopp, J. L., Jo, Y. R., and Reuel, N. F. (2019). Methods to reduce variability in E. Coli-based cell-free protein expression experiments. Synth. Syst. Biotechnol. 4, 204-211. doi: 10.1016/j.synbio.2019.10.003

Dubuc, E., Pieters, P. A., van der Linden, A. J., van Hest, J. C., Huck, W. T., and de Greef, T. F. (2019). Cell-free microcompartmentalised transcriptiontranslation for the prototyping of synthetic communication networks. Curr. Opin. Biotechnol. 58, 72-80. doi: 10.1016/j.copbio.2018.10.006

Dudley, Q. M., Karim, A. S., and Jewett, M. C. (2015). Cell-free metabolic engineering: biomanufacturing beyond the cell. Biotechnol. J. 10, 69-82. doi: 10.1002/biot.201400330

Duyen, T. T. M., Matsuura, H., Ujiie, K., Muraoka, M., Harada, K., and Hirata, K. (2017). Paper-based colorimetric biosensor for antibiotics inhibiting bacterial protein synthesis. J. Biosci. Bioeng. 123, 96-100. doi: 10.1016/j.jbiosc.2016.07. 015

Dvořák, P., Nikel, P. I., Damborský, J., and de Lorenzo, V. (2017). Bioremediation 3. 0: Engineering pollutant-removing bacteria in the times of systemic biology. Biotechnol. Adv. 35, 845-866. doi: 10.1016/j.biotechadv.2017.08.001

Dy, A. J., Aurand, E. R., and Friedman, D. C. (2019). YouTube resources for synthetic biology education. Synth. Biol. 4:ysz022. doi: 10.1093/synbio/ysz022

El Karoui, M., Hoyos-Flight, M., and Fletcher, L. (2019). Future trends in synthetic biology-a report. Front. Bioeng. Biotechnol. 7:175. doi: 10.3389/fbioe.2019. 00175

Endoh, T., Kanai, T., Sato, Y. T., Liu, D. V., Yoshikawa, K., Atomi, H., et al. (2006). Cell-free protein synthesis at high temperatures using the lysate of a hyperthermophile. J. Biotechnol. 126, 186-195. doi: 10.1016/j.jbiotec.2006.04. 010

Eriksen, M., Lebreton, L. C. M., Carson, H. S., Thiel, M., Moore, C. J., Borerro, J. C., et al. (2014). plastic pollution in the world's oceans: more than 5 Trillion plastic pieces weighing over 250,000 tons afloat at Sea. PLoS One 9:111913. doi: 10.1371 /journal.pone.0111913 
Exley, K., Reynolds, C. R., Suckling, L., Chee, S. M., Tsipa, A., Freemont, P. S., et al. (2019). Utilising datasheets for the informed automated design and build of a synthetic metabolic pathway. J. Biol. Eng. 13:8. doi: 10.1186/s13036-019-0141-Z

Ezure, T., Suzuki, T., Higashide, S., Shintani, E., Endo, K., Kobayashi, S.-I., et al. (2006). Cell-free protein synthesis system prepared from insect cells by freeze-thawing. Biotechnol. Prog. 22, 1570-1577. doi: 10.1021/bp060110v

Failmezger, J., Scholz, S., Blombach, B., and Siemann-Herzberg, M. (2018). Cellfree protein synthesis from fast-growing vibrio natriegens. Front. Microbiol. 9:1146. doi: 10.3389/fmicb.2018.01146

Foshag, D., Henrich, E., Hiller, E., Schäfer, M., Kerger, C., Burger-Kentischer, A., et al. (2018). The E. coli S30 lysate proteome: a prototype for cell-free protein production. N. Biotechnol. 40, 245-260. doi: 10.1016/j.nbt.2017.09.005

Freemont, P. S. (2019). Synthetic biology industry: data-driven design is creating new opportunities in biotechnology. Emerg. Top. Life Sci. 3, 651-657. doi: 10.1042/ETLS20190040

French, K. E. (2019). Harnessing synthetic biology for sustainable development. Nat. Sustain. 2, 250-252. doi: 10.1038/s41893-019-0270-x

Gagoski, D., Polinkovsky, M. E., Mureev, S., Kunert, A., Johnston, W., Gambin, Y., et al. (2016). Performance benchmarking of four cell-free protein expression systems. Biotechnol. Bioeng. 113, 292-300. doi: 10.1002/bit.25814

Gao, W., Cho, E., Liu, Y., and Lu, Y. (2019). Advances and challenges in cell-free incorporation of unnatural amino acids into proteins. Front. Pharmacol. 10:611. doi: 10.3389/fphar.2019.00611

Garamella, J., Marshall, R., Rustad, M., and Noireaux, V. (2016). The all E. coli TXTL toolbox 2.0: a platform for cell-free synthetic biology. ACS Synth. Biol. 5, 344-355. doi: 10.1021/acssynbio.5b00296

García-Manrique, P., Matos, M., Gutiérrez, G., Pazos, C., and Blanco-López, M. C. (2018). Therapeutic biomaterials based on extracellular vesicles: classification of bio-engineering and mimetic preparation routes. J. Extracell. Vesicles 7:1422676. doi: 10.1080/20013078.2017.1422676

Garenne, D., and Noireaux, V. (2019). Cell-free transcription-translation: engineering biology from the nanometer to the millimeter scale. Curr. Opin. Biotechnol. 58, 19-27. doi: 10.1016/j.copbio.2018.10.007

Georgi, V., Georgi, L., Blechert, M., Bergmeister, M., Zwanzig, M., Wüstenhagen, D. A., et al. (2016). On-chip automation of cell-free protein synthesis: new opportunities due to a novel reaction mode. Lab. Chip. 16, 269-281. doi: 10. 1039/C5LC00700C

Gessesse, B., Nagaike, T., Nagata, K., Shimizu, Y., and Ueda, T. (2018). G-protein coupled receptor protein synthesis on a lipid bilayer using a reconstituted cell-free protein synthesis system. Life 8:54. doi: 10.3390/life8040054

Gilbert, C., and Ellis, T. (2019). Biological engineered living materials: growing functional materials with genetically programmable properties. ACS Synth. Biol. 8, 1-15. doi: 10.1021/acssynbio.8b00423

Gills, B., and Morgan, J. (2019). Global climate emergency: after COP24, climate science, urgency, and the threat to humanity. Globalizations 1-18. doi: 10.1080/ 14747731.2019.1669915

Glasscock, C. J., Lucks, J. B., and DeLisa, M. P. (2016). Engineered protein machines: emergent tools for synthetic biology. Cell Chem. Biol. 23, 45-56. doi: 10.1016/j.chembiol.2015.12.004

Gowers, G.-O. F., Cameron, S. J. S., Perdones-Montero, A., Bell, D., Chee, S. M., Kern, M., et al. (2019). Off-colony screening of biosynthetic libraries by rapid laser-enabled mass spectrometry. ACS Synth. Biol. 8, 2566-2575. doi: 10.1021/ acssynbio.9b00243

Gräwe, A., Dreyer, A., Vornholt, T., Barteczko, U., Buchholz, L., Drews, G., et al. (2019). A paper-based, cell-free biosensor system for the detection of heavy metals and date rape drugs. PLoS One 14:e0210940. doi: 10.1371/journal.pone. 0210940

Greene, R. A., Morgan, M., Shatkin, A. J., and Gage, L. P. (1975). Translation of silk fibroin messenger RNA in an Ehrlich ascites cell-free extract. J. Biol. Chem. 250, 5114-5121.

Gregorio, N. E., Levine, M. Z., and Oza, J. P. (2019). A User's guide to cell-free protein synthesis. Methods Protoc. 2:24. doi: 10.3390/mps2010024

Grunberg, T. W., and Del Vecchio, D. (2020). Modular analysis and design of biological circuits. Curr. Opin. Biotechnol. 63, 41-47. doi: 10.1016/j.copbio. 2019.11.015

Gupta, S., Sarkar, S., Katranidis, A., and Bhattacharya, J. (2019). Development of a cell-free optical biosensor for detection of a broad range of mercury contaminants in water: a plasmid DNA-Based approach. ACS Omega 4, 94809487. doi: 10.1021/acsomega.9b00205

Ham, T. S., Dmytriv, Z., Plahar, H., Chen, J., Hillson, N. J., and Keasling, J. D. (2012). Design, implementation and practice of JBEI-ICE: an open source biological part registry platform and tools. Nucleic Acids Res. 40:e141. doi: 10.1093/nar/gks531

Han, X., Satoh, Y., Satoh, T., Matsumoto, K., Kakuchi, T., Taguchi, S., et al. (2011). Chemo-enzymatic synthesis of polyhydroxyalkanoate (PHA) incorporating 2hydroxybutyrate by wild-type class i PHA synthase from Ralstonia eutropha. Appl. Microbiol. Biotechnol. 92, 509-517. doi: 10.1007/s00253-011-3362-8

Harbers, M. (2014). Wheat germ systems for cell-free protein expression. FEBS Lett. 588, 2762-2773. doi: 10.1016/j.febslet.2014.05.061

Hecht, A., Glasgow, J., Jaschke, P. R., Bawazer, L. A., Munson, M. S., Cochran, J. R., et al. (2017). Measurements of translation initiation from all 64 codons in E. coli. Nucleic Acids Res. 45, 3615-3626. doi: 10.1093/nar/gkx070

Hicks, M., Bachmann, T. T., and Wang, B. (2020). Synthetic biology enables programmable cell-based biosensors. Chemphyschem 21, 132-144. doi: 10.1002/ cphc.201900739

Hillson, N., Caddick, M., Cai, Y., Carrasco, J. A., Chang, M. W., Curach, N. C., et al. (2019). Building a global alliance of biofoundries. Nat. Commun. 10:2040. doi: 10.1038/s41467-019-10079-2

Hiroe, A., Tsuge, K., Nomura, C. T., Itaya, M., and Tsuge, T. (2012). Rearrangement of gene order in the phaCAB operon leads to effective production of ultrahigh-molecular-weight poly[(R)-3-hydroxybutyrate] in genetically engineered Escherichia coli. Appl. Environ. Microbiol. 78, 3177-3184. doi: 10.1128/AEM.07715-11

Hodgman, C. E., and Jewett, M. C. (2013). Optimized extract preparation methods and reaction conditions for improved yeast cell-free protein synthesis. Biotechnol. Bioeng. 110, 2643-2654. doi: 10.1002/bit.24942

Hu, J., Xiao, K., Jin, B., Zheng, X., Ji, F., and Bai, D. (2019). Paper-based pointof-care test with xeno nucleic acid probes. Biotechnol. Bioeng. 116, 2764-2777. doi: 10.1002/bit.27106

$\mathrm{Hu}, \mathrm{S}$. J. (2013). Evolving paradigms of manufacturing: from mass production to mass customization and personalization. Procedia CIRP 7, 3-8. doi: 10.1016/j. procir.2013.05.002

Huang, A., Nguyen, P. Q., Stark, J. C., Takahashi, M. K., Donghia, N., Ferrante, T., et al. (2018). BiobitsTM explorer: a modular synthetic biology education kit. Sci. Adv. 4, 1-10. doi: 10.1126/sciadv.aat5105

Huang, P.-S., Boyken, S. E., and Baker, D. (2016). The coming of age of de novo protein design. Nature 537, 320-327. doi: 10.1038/nature19946

Huang, X., Li, M., Green, D. C., Williams, D. S., Patil, A. J., and Mann, S. (2013). Interfacial assembly of protein-polymer nano-conjugates into stimulus-responsive biomimetic protocells. Nat. Commun. 4:2239. doi: 10.1038/ ncomms3239

Jaworski, E., Wang, L., and Marco, G. (1963). Synthesis of chitin in cell-free extracts of prodenia eridania. Nature 198, 790-790. doi: 10.1038/198790a0

Jeong, D., Klocke, M., Agarwal, S., Kim, J., Choi, S., Franco, E., et al. (2019). Cellfree synthetic biology platform for engineering synthetic biological circuits and systems. Methods Protoc. 2:39. doi: 10.3390/mps2020039

Jessop-Fabre, M. M., and Sonnenschein, N. (2019). Improving reproducibility in synthetic biology. Front. Bioeng. Biotechnol. 7:18. doi: 10.3389/fbioe.2019.00018

Jiang, L., Zhao, J., Lian, J., and Xu, Z. (2018). Cell-free protein synthesis enabled rapid prototyping for metabolic engineering and synthetic biology. Synth. Syst. Biotechnol. 3, 90-96. doi: 10.1016/j.synbio.2018.02.003

Jiao, Y., Liu, Y., Luo, D., Huck, W. T. S., and Yang, D. (2018). Microfluidic-assisted fabrication of clay microgels for cell-free protein synthesis. ACS Appl. Mater. Interfaces 10, 29308-29313. doi: 10.1021/acsami.8b09324

Kanigowska, P., Shen, Y., Zheng, Y., Rosser, S., and Cai, Y. (2016). Smart DNA fabrication using sound waves. J. Lab. Autom. 21, 49-56. doi: 10.1177/ 2211068215593754

Karim, A. S., and Jewett, M. C. (2016). A cell-free framework for rapid biosynthetic pathway prototyping and enzyme discovery. Metab. Eng. 36, 116-126. doi: 10.1016/j.ymben.2016.03.002

Karim, A. S., and Jewett, M. C. (2018). Cell-free synthetic biology for pathway prototyping. Methods Enzymol. 608, 31-57. doi: 10.1016/bs.mie.2018.04.029

Katsura, K., Matsuda, T., Tomabechi, Y., Yonemochi, M., Hanada, K., Ohsawa, N., et al. (2017). A reproducible and scalable procedure for preparing bacterial 
extracts for cell-free protein synthesis. J. Biochem. 162, 357-369. doi: 10.1093/ $\mathrm{jb} / \mathrm{mvx} 039$

Kay, J. E., and Jewett, M. C. (2020). A cell-free system for production of 2,3-butanediol is robust to growth-toxic compounds. Metab. Eng. Commun. 10:e00114. doi: 10.1016/j.mec.2019.e00114

Kelly, J. R., Rubin, A. J., Davis, J. H., Ajo-Franklin, C. M., Cumbers, J., Czar, M. J., et al. (2009). Measuring the activity of BioBrick promoters using an in vivo reference standard. J. Biol. Eng. 3:4. doi: 10.1186/1754-1611-3-4

Kelwick, R., Bowater, L., Yeoman, K. H., and Bowater, R. P. (2015a). Promoting microbiology education through the iGEM synthetic biology competition. FEMS Microbiol. Lett. 362:fnv129. doi: 10.1093/femsle/fn v129

Kelwick, R., Kopniczky, M., Bower, I., Chi, W., Chin, M. H. W., Fan, S., et al. (2015b). A Forward-design approach to increase the production of poly-3-hydroxybutyrate in genetically engineered Escherichia coli. PLoS One 10:e0117202. doi: 10.1371/journal.pone.0117202

Kelwick, R., MacDonald, J. T., Webb, A. J., and Freemont, P. (2014). Developments in the tools and methodologies of synthetic biology. Front. Bioeng. Biotechnol. 2:60. doi: 10.3389/fbioe.2014.00060

Kelwick, R., Ricci, L., Chee, S. M., Bell, D., Webb, A. J., and Freemont, P. S. (2018). Cell-free prototyping strategies for enhancing the sustainable production of polyhydroxyalkanoates bioplastics. Synth. Biol. 3:ysy016. doi: 10.1093/synbio/ ysy016

Kelwick, R., Webb, A. J., MacDonald, J. T., and Freemont, P. S. (2016). Development of a Bacillus subtilis cell-free transcription-translation system for prototyping regulatory elements. Metab. Eng. 38, 370-381. doi: 10.1016/j. ymben.2016.09.008

Khambhati, K., Bhattacharjee, G., Gohil, N., Braddick, D., Kulkarni, V., and Singh, V. (2019). Exploring the potential of cell-free protein synthesis for extending the abilities of biological systems. Front. Bioeng. Biotechnol. 7:248. doi: 10.3389/ fbioe. 2019.00248

Kightlinger, W., Duncker, K. E., Ramesh, A., Thames, A. H., Natarajan, A., Stark, J. C., et al. (2019). A cell-free biosynthesis platform for modular construction of protein glycosylation pathways. Nat. Commun. 10, 1-13. doi: 10.1038/s41467019-12024-9

Kilb, N., Burger, J., and Roth, G. (2014). Protein microarray generation by in situ protein expression from template DNA. Eng. Life Sci. 14, 352-364. doi: 10.1002/ elsc. 201300052

Kim, B. S. (2000). Production of poly(3-hydroxybutyrate) from inexpensive substrates. Enzyme Microb. Technol. 27, 774-777. doi: 10.1016/s0141-0229(00) 00299-4

Kleer, R., and Piller, F. T. (2019). Local manufacturing and structural shifts in competition: market dynamics of additive manufacturing. Int. J. Prod. Econ. 216, 23-34. doi: 10.1016/j.ijpe.2019.04.019

Kopniczky, M. B., Canavan, C., McClymont, D. W., Crone, M. A., Suckling, L., Goetzmann, B., et al. (2020). Cell-free protein synthesis as a prototyping platform for mammalian synthetic biology. ACS Synth. Biol. 9, 144-156. doi: 10.1021/acssynbio.9b00437

Kopp, D., Willows, R. D., and Sunna, A. (2019). Cell-free enzymatic conversion of spent coffee grounds into the platform chemical lactic acid. Front. Bioeng. Biotechnol. 7:389. doi: 10.3389/fbioe.2019.00389

Korman, T. P., Opgenorth, P. H., and Bowie, J. U. (2017). A synthetic biochemistry platform for cell free production of monoterpenes from glucose. Nat. Commun. 8:15526. doi: 10.1038/ncomms 15526

Kovtun, O., Mureev, S., Johnston, W., and Alexandrov, K. (2010). Towards the construction of expressed proteomes using a Leishmania tarentolae based cellfree expression system. PLoS One 5:e14388. doi: 10.1371/journal.pone.0014388

Kovtun, O., Mureev, S., Jung, W., Kubala, M. H., Johnston, W., and Alexandrov, K. (2011). Leishmania cell-free protein expression system. Methods 55, 58-64. doi: 10.1016/j.ymeth.2011.06.006

Krinsky, N., Kaduri, M., Shainsky-Roitman, J., Goldfeder, M., Ivanir, E., Benhar, I., et al. (2016). A simple and rapid method for preparing a cell-free bacterial lysate for protein synthesis. PLoS One 11:e0165137. doi: 10.1371/journal.pone. 0165137

Krishnan, S., Narayan, S., and Chadha, A. (2016). Whole resting cells vs. cell free extracts of Candida parapsilosis ATCC 7330 for the synthesis of gold nanoparticles. AMB Express 6:92. doi: 10.1186/s13568-016-0268-y
Kwon, Y.-C., and Jewett, M. C. (2015). High-throughput preparation methods of crude extract for robust cell-free protein synthesis. Sci. Rep. 5:8663. doi: $10.1038 /$ srep08663

Lai, H.-E., Canavan, C., Cameron, L., Moore, S., Danchenko, M., Kuiken, T., et al. (2019). Synthetic biology and the united nations. Trends Biotechnol. 37, 1146-1151. doi: 10.1016/j.tibtech.2019.05.011

Lavickova, B., and Maerkl, S. J. (2019). A simple, robust, and low-cost method to produce the pure cell-free system. ACS Synth. Biol. 8, 455-462. doi: 10.1021/ acssynbio.8b00427

Le Feuvre, R. A., and Scrutton, N. S. (2018). A living foundry for synthetic biological materials: a synthetic biology roadmap to new advanced materials. Synth. Syst. Biotechnol. 3, 105-112. doi: 10.1016/j.synbio.2018.04.002

Lee, K.-H., and Kim, D.-M. (2019). In vitro use of cellular synthetic machinery for biosensing applications. Front. Pharmacol. 10:1166. doi: 10.3389/fphar.2019. 01166

Lenton, T. M., Rockström, J., Gaffney, O., Rahmstorf, S., Richardson, K., Steffen, W., et al. (2019). Climate tipping points - too risky to bet against. Nature 575, 592-595. doi: 10.1038/d41586-019-03595-0

Li, J., Wang, H., and Jewett, M. C. (2018). Expanding the palette of Streptomyces -based cell-free protein synthesis systems with enhanced yields. Biochem. Eng. J. 130, 29-33. doi: 10.1016/j.bej.2017.11.013

Li, T., Ye, J., Shen, R., Zong, Y., Zhao, X., Lou, C., et al. (2016). Semirational approach for ultrahigh Poly(3-hydroxybutyrate) accumulation in Escherichia coli by combining one-step library construction and high-throughput screening. ACS Synth. Biol. 5, 1308-1317. doi: 10.1021/acssynbio.6b00083

Libicher, K., Hornberger, R., Heymann, M., and Mutschler, H. (2020). In vitro self-replication and multicistronic expression of large synthetic genomes. Nat. Commun. 11:904. doi: 10.1038/s41467-020-14694-2

Lim, S. Y., Kim, K.-O., Kim, D.-M., and Park, C. B. (2009). Silica-coated alginate beads for in vitro protein synthesis via transcription/translation machinery encapsulation. J. Biotechnol. 143, 183-189. doi: 10.1016/j.jbiotec.2009.07.006

Liu, R., Fu, A., Deng, Z., Li, Y., and Liu, T. (2020). Promising methods for detection of novel coronavirus SARS-CoV-2. View 1:e4. doi: 10.1002/viw2.4

Liu, Y., Zhao, T., Ju, W., Shi, S., Shi, S., and Shi, S. (2017). Materials discovery and design using machine learning. J. Mater. 3, 159-177. doi: 10.1016/j.jmat.2017. 08.002

Lizardi, P. M., Mahdavi, V., Shields, D., and Candelas, G. (1979). Discontinuous translation of silk fibroin in a reticulocyte cell-free system and in intact silk gland cells. Proc. Natl. Acad. Sci. 76, 6211-6215. doi: 10.1073/pnas.76.12.6211

Madsen, C., Goñi Moreno, A., Umesh, P., Palchick, Z., Roehner, N., Atallah, C., et al. (2019). Synthetic biology open language (SBOL) Version 2.3. J. Integr. Bioinform. 16:25. doi: 10.1515/jib-2019-0025

Martin, R. W., Des Soye, B. J., Kwon, Y.-C., Kay, J., Davis, R. G., Thomas, P. M., et al. (2018). Cell-free protein synthesis from genomically recoded bacteria enables multisite incorporation of noncanonical amino acids. Nat. Commun. 9:1203. doi: 10.1038/s41467-018-03469-5

Martin, R. W., Majewska, N. I., Chen, C. X., Albanetti, T. E., Jimenez, R. B. C., Schmelzer, A. E., et al. (2017). Development of a CHO-based cell-free platform for synthesis of active monoclonal antibodies. ACS Synth. Biol. 6, 1370-1379. doi: 10.1021/acssynbio.7b00001

Matsumoto, K. K., Okei, T., Honma, I., Ooi, T., Aoki, H., and Taguchi, S. (2013). Erratum to: Efficient (R)-3-hydroxybutyrate production using acetyl CoAregenerating pathway catalyzed by coenzyme A transferase. Appl. Microbiol. Biotechnol. 97, 439-439. doi: 10.1007/s00253-012-4563-5

McLaughlin, J. A., Myers, C. J., Zundel, Z., M $\imath$ s $\iota$ rl $\imath$, G., Zhang, M., Ofiteru, I. D., et al. (2018). SynBioHub: a standards-enabled design repository for synthetic biology. ACS Synth. Biol. 7, 682-688. doi: 10.1021/acssynbio.7b00403

Miguez, A. M., McNerney, M. P., and Styczynski, M. P. (2019). Metabolic profiling of Escherichia coli -based cell-free expression systems for process optimization. Ind. Eng. Chem. Res. 58, 22472-22482. doi: 10.1021/acs.iecr.9b03565

Misirli, G., Nguyen, T., McLaughlin, J. A., Vaidyanathan, P., Jones, T. S., Densmore, D., et al. (2019). A computational workflow for the automated generation of models of genetic designs. ACS Synth. Biol. 8, 1548-1559. doi: 10.1021/ acssynbio.7b00459

Moore, S. J., Lai, H.-E., Needham, H., Polizzi, K. M., and Freemont, P. S. (2017a). Streptomyces venezuelae TX-TL - a next generation cell-free synthetic biology tool. Biotechnol. J. 12:1600678. doi: 10.1002/biot.201600678 
Moore, S. J., MacDonald, J. T., and Freemont, P. S. (2017b). Cell-free synthetic biology for in vitro prototype engineering. Biochem. Soc. Trans. 45, 785-791. doi: 10.1042/BST20170011

Moore, S. J., MacDonald, J. T., Wienecke, S., Ishwarbhai, A., Tsipa, A., Aw, R., et al. (2018). Rapid acquisition and model-based analysis of cell-free transcriptiontranslation reactions from nonmodel bacteria. Proc. Natl. Acad. Sci. U.S.A. 115, E4340-E4349. doi: 10.1073/pnas.1715806115

Mureev, S., Kovtun, O., Nguyen, U. T. T., and Alexandrov, K. (2009). Speciesindependent translational leaders facilitate cell-free expression. Nat. Biotechnol. 27, 747-752. doi: 10.1038/nbt.1556

Nahvi, A., Sudarsan, N., Ebert, M. S., Zou, X., Brown, K. L., and Breaker, R. R. (2002). Genetic control by a metabolite binding mRNA. Chem. Biol. 9, 10431049. doi: 10.1016/S1074-5521(02)00224-7

Niederholtmeyer, H., Sun, Z. Z., Hori, Y., Yeung, E., Verpoorte, A., Murray, R. M., et al. (2015). Rapid cell-free forward engineering of novel genetic ring oscillators. eLife 4:e09771. doi: 10.7554/eLife.09771

Nielsen, A. A. K., Der, B. S., Shin, J., Vaidyanathan, P., Paralanov, V., Strychalski, E. A., et al. (2016). Genetic circuit design automation. Science 352:7341. doi: 10.1126/science.aac7341

Nielsen, C., Rahman, A., Rehman, A. U., Walsh, M. K., and Miller, C. D. (2017). Food waste conversion to microbial polyhydroxyalkanoates. Microb. Biotechnol. 2:12776. doi: 10.1111/1751-7915.12776

Nikel, P. I., de Almeida, A., Melillo, E. C., Galvagno, M. A., and Pettinari, M. J. (2006). New recombinant Escherichia coli strain tailored for the production of poly(3-hydroxybutyrate) from agroindustrial by-products. Appl. Environ. Microbiol. 72, 3949-3954. doi: 10.1128/AEM.00044-06

Ogonah, O. W., Polizzi, K. M., and Bracewell, D. G. (2017). Cell free protein synthesis: a viable option for stratified medicines manufacturing? Curr. Opin. Chem. Eng. 18, 77-83. doi: 10.1016/j.coche.2017.10.003

O'Kane, P. T., Dudley, Q. M., McMillan, A. K., Jewett, M. C., and Mrksich, M. (2019). High-throughput mapping of CoA metabolites by SAMDI-MS to optimize the cell-free biosynthesis of HMG-CoA. Sci. Adv. 5:eaaw9180. doi: 10.1126/sciadv.aaw9180

Opgenorth, P. H., Korman, T. P., and Bowie, J. U. (2016). A synthetic biochemistry module for production of bio-based chemicals from glucose. Nat. Chem. Biol. 12, 1-4. doi: 10.1038/nchembio.2062

Pardee, K. (2018). Perspective: solidifying the impact of cell-free synthetic biology through lyophilization. Biochem. Eng. J. 138, 91-97. doi: 10.1016/j.bej.2018.07. 008

Pardee, K., Green, A. A., Ferrante, T., Cameron, D. E., DaleyKeyser, A., Yin, P., et al. (2014). Paper-based synthetic gene networks. Cell 159, 940-954. doi: 10.1016/j.cell.2014.10.004

Pardee, K., Green, A. A., Takahashi, M. K., Braff, D., Lambert, G., Lee, J. W., et al. (2016a). Rapid, low-cost detection of zika virus using programmable biomolecular components. Cell 165, 1255-1266. doi: 10.1016/j.cell.2016.04.059

Pardee, K., Slomovic, S., Nguyen, P. Q., Lee, J. W., Donghia, N., Burrill, D., et al. (2016b). Portable, on-demand biomolecular manufacturing. Cell 167, 248.e-259.e. doi: 10.1016/j.cell.2016.09.013

Park, N., Kahn, J. S., Rice, E. J., Hartman, M. R., Funabashi, H., Xu, J., et al. (2009a). High-yield cell-free protein production from P-gel. Nat. Protoc. 4, 1759-1770. doi: 10.1038/nprot.2009.174

Park, N., Um, S. H., Funabashi, H., Xu, J., and Luo, D. (2009b). A cell-free protein-producing gel. Nat. Mater. 8, 432-437. doi: 10.1038/nmat2419

Philp, J. (2018). The bioeconomy, the challenge of the century for policy makers. N. Biotechnol. 40, 11-19. doi: 10.1016/j.nbt.2017.04.004

Rajakumar, P. D., Gowers, G.-O. F., Suckling, L., Foster, A., Ellis, T., Kitney, R. I., et al. (2019). Rapid prototyping platform for Saccharomyces cerevisiae using computer-aided genetic design enabled by parallel software and workcell platform development. SLAS Technol. Transl. Life Sci. Innov. 24, 291-297. doi: 10.1177/2472630318798304

Roberts, A. D., Finnigan, W., Wolde-Michael, E., Kelly, P., Blaker, J. J., Hay, S., et al. (2019). Synthetic biology for fibers, adhesives, and active camouflage materials in protection and aerospace. MRS Commun. 9, 486-504. doi: 10.1557/mrc.2019. 35

Roell, M.-S., and Zurbriggen, M. D. (2020). The impact of synthetic biology for future agriculture and nutrition. Curr. Opin. Biotechnol. 61, 102-109. doi: 10. 1016/j.copbio.2019.10.004
Rolf, J., Rosenthal, K., and Lütz, S. (2019). Application of cell-free protein synthesis for faster biocatalyst development. Catalysts 9:190. doi: 10.3390/catal9020190

Rues, R.-B., Henrich, E., Boland, C., Caffrey, M., and Bernhard, F. (2016). Cellfree production of membrane proteins in Escherichia coli lysates for functional and structural studies. Methods Mol. Biol. 1432, 1-21. doi: 10.1007/978-1-49393637-3_1

Ruiz, R. C. H., Kiatwuthinon, P., Kahn, J. S., Roh, Y. H., and Luo, D. (2012). Cellfree protein expression from DNA-based hydrogel (P-Gel) droplets for scale-up production. Ind. Biotechnol. 8, 372-377. doi: 10.1089/ind.2012.0024

Russo, D. A., Zedler, J. A. Z., and Jensen, P. E. (2019). A force awakens: exploiting solar energy beyond photosynthesis. J. Exp. Bot. 70, 1703-1710. doi: 10.1093/ jxb/erz054

Rustad, M., Eastlund, A., Jardine, P., and Noireaux, V. (2018). Cell-free TXTL synthesis of infectious bacteriophage T4 in a single test tube reaction. Synth. Biol. 3, 1-7. doi: 10.1093/synbio/ysy002

Salehi, A. S. M., Shakalli Tang, M. J., Smith, M. T., Hunt, J. M., Law, R. A., Wood, D. W., et al. (2017). Cell-Free protein synthesis approach to biosensing hTR $\beta$ specific endocrine disruptors. Anal. Chem. 89, 3395-3401. doi: 10.1021/acs. analchem.6b04034

Salehi, A. S. M., Smith, M. T., Bennett, A. M., Williams, J. B., Pitt, W. G., and Bundy, B. C. (2016). Cell-free protein synthesis of a cytotoxic cancer therapeutic: onconase production and a just-add-water cell-free system. Biotechnol. J. 11, 274-281. doi: 10.1002/biot.201500237

Shelby, M. L., He, W., Dang, A. T., Kuhl, T. L., and Coleman, M. A. (2019). Cell-free co-translational approaches for producing mammalian receptors: expanding the cell-free expression toolbox using nanolipoproteins. Front. Pharmacol. 10:744. doi: 10.3389/fphar.2019.00744

Shimizu, Y., Inoue, A., Tomari, Y., Suzuki, T., Yokogawa, T., Nishikawa, K., et al. (2001). Cell-free translation reconstituted with purified components. Nat. Biotechnol. 19, 751-755. doi: 10.1038/90802

Shimizu, Y., Kanamori, T., and Ueda, T. (2005). Protein synthesis by pure translation systems. Methods 36, 299-304. doi: 10.1016/j.ymeth.2005.04.006

Shin, J., and Noireaux, V. (2012). An E. coli cell-free expression toolbox: application to synthetic gene circuits and artificial cells. ACS Synth. Biol. 1, 29-41. doi: $10.1021 / \mathrm{sb} 200016 \mathrm{~s}$

Shinoda, T., Shinya, N., Ito, K., Ishizuka-Katsura, Y., Ohsawa, N., Terada, T., et al. (2016). Cell-free methods to produce structurally intact mammalian membrane proteins. Sci. Rep. 6, 1-15. doi: 10.1038/srep30442

Shurtleff, M. J., Temoche-Diaz, M. M., Karfilis, K. V., Ri, S., and Schekman, R. (2016). Y-box protein 1 is required to sort microRNAs into exosomes in cells and in a cell-free reaction. Elife 5, 1-23. doi: 10.7554/eLife.19276

Silverman, A. D., Karim, A. S., and Jewett, M. C. (2019). Cell-free gene expression: an expanded repertoire of applications. Nat. Rev. Genet. 21, 151-170. doi: 10. 1038/s41576-019-0186-3

Smith, M. T., and Berkheimer, S. D. (2014). Lyophilized Escherichia coli -based cellfree systems for robust, high-density, long-term storage. Biotechniques 56:158. doi: $10.2144 / 000114158$

Stock, T., and Seliger, G. (2016). Opportunities of sustainable manufacturing in industry 4.0. Proc. CIRP 40, 536-541. doi: 10.1016/j.procir.2016.01.129

Storch, M., Haines, M. C., and Baldwin, G. S. (2019). DNA-BOT: a low-cost, automated DNA assembly platform for synthetic biology. bioRxiv [Preprint], doi: 10.1101/832139

Sullivan, C. J., Pendleton, E. D., Sasmor, H. H., Hicks, W. L., Farnum, J. B., Muto, M., et al. (2016). A cell-free expression and purification process for rapid production of protein biologics. Biotechnol. J. 11, 238-248. doi: 10.1002/biot. 201500214

Sun, Z. Z., Hayes, C. A., Shin, J., Caschera, F., Murray, R. M., and Noireaux, V. (2013). Protocols for implementing an Escherichia coli based TX-TL cellfree expression system for synthetic biology. J. Vis. Exp. e50762. doi: 10.3791/ 50762

Sun, Z. Z., Yeung, E., Hayes, C. A., Noireaux, V., and Murray, R. M. (2014). Linear DNA for rapid prototyping of synthetic biological circuits in an Escherichia coli Based TX-TL cell-free system. ACS Synth. Biol. 3, 387-397. doi: 10.1021/ sb400131a

Swank, Z., Laohakunakorn, N., and Maerkl, S. J. (2019). Cell-free gene-regulatory network engineering with synthetic transcription factors. Proc. Natl. Acad. Sci. U.S.A. 116, 5892-5901. doi: 10.1073/pnas.1816591116 
Tan, D., Xue, Y.-S., Aibaidula, G., and Chen, G.-Q. (2011). Unsterile and continuous production of polyhydroxybutyrate by halomonas TD01. Bioresour. Technol. 102, 8130-8136. doi: 10.1016/j.biortech.2011.05.068

Tao, W., Lv, L., and Chen, G.-Q. (2017). Engineering halomonas species TD01 for enhanced polyhydroxyalkanoates synthesis via CRISPRi. Microb. Cell Fact. 16:48. doi: 10.1186/s12934-017-0655-3

Tarrahi, R., Fathi, Z., Seydibeyoğlu, M. Ö, Doustkhah, E., and Khataee, A. (2020). Polyhydroxyalkanoates (PHA): from production to nanoarchitecture. Int. J. Biol. Macromol. 146, 596-619. doi: 10.1016/j.ijbiomac.2019.12.181

Thavarajah, W., Silverman, A. D., Verosloff, M. S., Kelley-Loughnane, N., Jewett, M. C., and Lucks, J. B. (2020). Point-of-use detection of environmental fluoride via a cell-free riboswitch-based biosensor. ACS Synth. Biol. 9, 10-18. doi: 10. 1021/acssynbio.9b00347

Thomson, N., Roy, I., Summers, D., and Sivaniah, E. (2009). In vitro production of polyhydroxyalkanoates: achievements and applications. J. Chem. Technol. Biotechnol. 85, 760-767. doi: 10.1002/jctb.2299

Tomizawa, S., Yoshioka, M., Ushimaru, K., and Tsuge, T. (2012). Preparative synthesis of Poly(R)-3-hydroxybutyrate monomer for enzymatic cell-free polymerization. Polym. J. 44, 982-985. doi: 10.1038/pj.2012.34

Townsend, T., and Sette, J. (2016). "Natural fibres and the world economy," in Natural Fibres: Advances in Science and Technology Towards Industrial Applications, eds R. Fangueiro and S. Rana (Dordrecht: Springer), 381-390. doi: 10.1007/978-94-017-7515-1_30

Trump, B. D., Cegan, J., Wells, E., Poinsatte-Jones, K., Rycroft, T., Warner, C., et al. (2019). Co-evolution of physical and social sciences in synthetic biology. Crit. Rev. Biotechnol. 39, 351-365. doi: 10.1080/07388551.2019.1566203

Ullah, M. W., Ul-Islam, M., Khan, S., Kim, Y., and Park, J. K. (2015). Innovative production of bio-cellulose using a cell-free system derived from a single cell line. Carbohydr. Polym. 132, 286-294. doi: 10.1016/j.carbpol.2015. 06.037

Voyvodic, P. L., Pandi, A., Koch, M., Conejero, I., Valjent, E., Courtet, P., et al. (2019). Plug-and-play metabolic transducers expand the chemical detection space of cell-free biosensors. Nat. Commun. 10:1697. doi: 10.1038/s41467-01909722-9

Wagner, H. J., Engesser, R., Ermes, K., Geraths, C., Timmer, J., and Weber, W. (2019). Synthetic biology-inspired design of signal-amplifying materials systems. Mater. Today 22, 25-34. doi: 10.1016/j.mattod.2018.04.006

Walsh, D. I., Pavan, M., Ortiz, L., Wick, S., Bobrow, J., Guido, N. J., et al. (2019). Standardizing automated DNA assembly: best practices, metrics, and protocols using robots. SLAS Technol. Transl. Life Sci. Innov. 24, 282-290. doi: 10.1177/ 2472630318825335

Wan, X., Volpetti, F., Petrova, E., French, C., Maerkl, S. J., and Wang, B. (2019). Cascaded amplifying circuits enable ultrasensitive cellular sensors for toxic metals. Nat. Chem. Biol. 15, 540-548. doi: 10.1038/s41589-019-0244-3
Weber, L. A., Feman, E. R., and Baglioni, C. (1975). Cell free system from HeLa cells active in initiation of protein synthesis. Biochemistry 14, 5315-5321. doi: 10.1021/bi00695a015

Wen, K. Y., Cameron, L., Chappell, J., Jensen, K., Bell, D. J., Kelwick, R., et al. (2017). A Cell-free biosensor for detecting quorum sensing molecules in P. aeruginosa -infected respiratory samples. ACS Synth. Biol. 6, 2293-2301. doi: 10.1021/acssynbio.7b00219

Wilding, K. M., Schinn, S.-M., Long, E. A., and Bundy, B. C. (2018). The emerging impact of cell-free chemical biosynthesis. Curr. Opin. Biotechnol. 53, 115-121. doi: 10.1016/j.copbio.2017.12.019

Wong, H. H., and Lee, S. Y. (1998). Poly-(3-hydroxybutyrate) production from whey by high-density cultivation of recombinant Escherichia coli. Appl. Microbiol. Biotechnol. 50, 30-33. doi: 10.1007/s002530051252

Yan, Q., and Fong, S. S. (2015). Bacterial chitinase: nature and perspectives for sustainable bioproduction. Bioresour. Bioprocess. 2:31. doi: 10.1186/s40643015-0057-5

Yim, S. S., Johns, N. I., Park, J., Gomes, A. L., McBee, R. M., Richardson, M., et al. (2019). Multiplex transcriptional characterizations across diverse bacterial species using cell-free systems. Mol. Syst. Biol. 15:875. doi: 10.15252/msb. 20198875

Yue, K., Zhu, Y., and Kai, L. (2019). Cell-free protein synthesis: chassis toward the minimal cell. Cells 8:315. doi: 10.3390/cells8040315

Zawada, J. F., Yin, G., Steiner, A. R., Yang, J., Naresh, A., Roy, S. M., et al. (2011). Microscale to manufacturing scale-up of cell-free cytokine production-a new approach for shortening protein production development timelines. Biotechnol. Bioeng. 108, 1570-1578. doi: 10.1002/bit.23103

Zhang, X., Lin, Y., Wu, Q., Wang, Y., and Chen, G.-Q. (2019). Synthetic biology and genome-editing tools for improving pha metabolic engineering. Trends Biotechnol. doi: 10.1016/j.tibtech.2019.10.006

Zhang, Y., Minagawa, Y., Kizoe, H., Miyazaki, K., Iino, R., Ueno, H., et al. (2019). Accurate high-throughput screening based on digital protein synthesis in a massively parallel femtoliter droplet array. Sci. Adv. 5:eaav8185. doi: 10.1126/ sciadv.aav8185

Conflict of Interest: The authors declare that the research was conducted in the absence of any commercial or financial relationships that could be construed as a potential conflict of interest.

Copyright (c) 2020 Kelwick, Webb and Freemont. This is an open-access article distributed under the terms of the Creative Commons Attribution License (CC BY). The use, distribution or reproduction in other forums is permitted, provided the original author(s) and the copyright owner(s) are credited and that the original publication in this journal is cited, in accordance with accepted academic practice. No use, distribution or reproduction is permitted which does not comply with these terms. 